\title{
Does the Percentage of Investment Grades Given by Rating Agencies Impact their Market Share?
}

\author{
http://doi.org/10.21272/fmir.4(1).5-31.2020
}

Muhammad Adnan Aslam, ORCID: orcid.org/0000-0003-4501-9904

Teaching Assistant, Post Graduate Researcher, Association of Chartered Certified Accountants (ACCA), Centre for Financial and Corporate Integrity, Faculty of Business and Law, Coventry University, Great Britain

\begin{abstract}
The credit ratings industry has controlled by three core credit ratings agencies; Fitch, Moody's and S\&P that are contributing to financial markets by providing reliable and transparent credit ratings information on which stakeholders can rely. These key players could manipulate this information by allocating high percentages of quality ratings just for the sake of increasing their market shares. This research is conducting to examine the impact for assigning the percentage of investment grades given by CRA's on their market share. This research will attain following objectives: firstly, to identify quality ratings assigned for each set of top banks from UK \& USA and categories them yearly; secondly, to examine their market share on the basis of percentage of IG grade given; thirdly, to access the modeling and impacts of financial crisis on market share of CRA's; finally, to determine the relationship between CRA's market share and percentage of IG given.
\end{abstract}

This research gives a detailed analysis for percentage of IG assigned by CRA's and their market share which consist on general analysis and econometric analysis. Moreover, the research methodology is quantitative method for achieving all research objectives. For general analysis, we make a comparative study to find the impacts of high-quality ratings against their market share and evaluated the growth rate in their market share. Whereas, for econometrics analysis, we regress market share of CRA's against the percentage of investment grades given and use lagged variables to understand the changes in market share. Besides, this allows us to find the relationship between CRA's and percentage of IG given. Hence, the results from both analyses have exposed that there is positive correlation between CRA's market share and percentage of IG given. It is revealed that there is an increase in market share of CRA's on assigning high percentage of IG given by CRA's and a negative growth rate shown in market share for those years in which they allocate less number of quality ratings. However, due to financial crisis and adjustment in credit ratings standards, there is a general fall in number of ratings assigned by CRA's which very influences their market share.

Keywords: investment grades; market share; credit rating agencies; financial crisis; modelling of banks ratings.

JEL Classification: D20, D40, G01, G21, G24, C50, F39.

(C) The Authors, 2020. This article is published with open access at Sumy State University.

This work is licensed under a Creative Commons Attribution 4.0 International License

Cite as: Aslam, M. A. (2020). Does the Percentage of Investment Grades Given by Rating Agencies Impact their Market Share? Financial Markets, Institutions and Risks, 4(1), 5-31. http://doi.org/10.21272/fmir.4(1).531.2020.

\section{Introduction}

\subsection{Background}

Credit ratings is a vital part of the economies as it conveys about their financial position and outlook which enable to assist in decision making process. As described by Moody's "the credit rating is an opinion about the Creditworthiness of an entity issued by using an established and defined ranking system of ratings categories" (Moody's Investor Service 2020) ${ }^{1}$. These are the views conveyed on an alphanumeric scale on the comparative capacity and willingness of a debt issuer to fulfill its financial obligations. There are two grades of credit ratings which are "investment grade" and "speculative grade". The investment grade sets comparatively low risk to moderate risk which includes ratings from "AAA" to "BBB" while speculative

1 Also, see the Ratings Definitions by Fitch Ratings. Available at https://www.fitchratings.com/site/definitions 
grade indicates a high level of risk or the default that previously occur which includes ratings from "BB" to "D".

The credit rating agencies (CRA's) are playing a central role in assigning these ratings and considered as dominant organizations because they can impact the issuer existence through disturbing their access to capital market which cause a dysfunction in these financial markets due to low quality ratings assigned. These dysfunctions caused break down in designed financial products in shape of financial crisis (Griffin and Tang 2012). They found that a principal credit ratings agency made positive alterations in their credit ratings model for the sake of increasing the size of AAA tranches by examining Collateralized debt obligations (CDO's). So, their assessments are vital regarding financial stability viewpoint because they have to reflect the correct ratings information in the market which influence the stakeholder's decisions. For achieving the required quality information and protecting the stakeholder's interest a number of regulations introduced. The DoddFrank Act have a serious impact on CRA's because it explains that credit ratings have a systematic importance and CRA's act as gatekeeper in the debt market (Dimitrov et al 2015). Moreover, CRA's must resolve the conflict of interests and due to inaccurate ratings standards having an adverse impact on economy during financial crisis (PWC report 2010). The Securities and Exchange Commission (2012) have proposed to refine the ratings criteria's by increasing the rivalry between CRA's because they are acting as key players in the markets according Credit Ratings Agency Reforms Acts 2006. The motivation behind assigning precise ratings rely on market conditions, asset distribution in economy and business competition between CRA's (Kartashevay and Yilmaz 2013). Moreover, they argued that the ratings become less accurate as these factors involves such as uninformed investors and rise in gains of trade.

During financial crisis, performance of CRA's vary between diverse asset classes because asset-backed securities remains at AAA ratings (Stanton and Wallace, 2011). But other affected the most because CRA's have assigned IG ratings to them just for their own interest regardless considering investors interest. As cited in Financial Crisis Inquiry Reports (2011) that CRA's used incorrect credit ratings models for the sake of growing their market share and profits. Also, CRA's have updated their ratings criteria's which leads to the consequences of severe condemnation from the stakeholders which means that CRA's have neglected their criteria's for the desire of growing their market share. If we look at their market share, according to Reuters News, big three CRA's are accounted for approximately 2.30 million out of 2.42 million credit ratings overdue by the end 2014. As stated by UK Government Actuary's Department (2018) that the credit rating is an extremely intensive industry and "Big Three" collectively controlling around $95 \%$ of the business ratings. In this S\&P and Moody's having a control on 40\% each in global market. Whereas, Fitch is having 15\% and others having 5\% control on global market (investment News 2018). Moreover, Cantor \& Packer (1994) stated that the CRA's have disputes of interest in their business models. CRA's might allocate an inflated or lower credit ratings to firms when they try pay for their own credit ratings practices. CRA's could menacing the firms for making their business worse by giving lower ratings or they can pay for higher ratings (Hill 2004). Because in market if any firm gets higher ratings than investors think that it is a secure source of investment and they start investing in it. According to Forbes, Moody's investor's service decided to pay \$130 million for the resolving a lawsuit by California Public Employees Retirement system (CALPERS) of worth \$1 billion which filed against Fitch, Moody's and S\&P in 2009 (Rutledge 2016). This is because the CALPERS accused CRA's to assigning higher ratings to a loss-making business due to their negligence in which they have invested. This act due to negligence or might be for the sake of increasing their market share by assigning higher percentage of IG to specific firms because credit analysis is an intelligent discipline which needs a participant's comprehending of financial games.

As highlighted above big three have captured almost all the credit ratings market in term of number of ratings assigned to different organizations. As mentioned in literature review chapter, most of studies focus on regulation and general market share of CRA's regardless the percentage of investment grade assigned. So, this research is based on a set of banks from UK and USA for analyzing the impacts on market share of CRA's in term of percentage of investment grade ratings assigned from 2006 to 2018. The reason behind for choosing the set of banks from UK and USA because these banks are key players in the world and their credit ratings are main factor for the investors in term of making decisions regarding their investments. By accessing the market share of CRA's based on percentage of investment grade ratings assigned than we will be able to analyze that how generous, they are in assigning the high-quality ratings just for their own self-interest. 


\subsection{Research Aim}

The aim of this research is to study and assess the market share of CRA's driven by percentage of investment grade credit ratings assigned for set of banks from UK and USA for period (2006-2018).

\subsection{Research Scope}

The key purpose of this research is to analyze the effects of quality ratings assigned by CRA's on their market share. How generous the CRA's in assigning number of quality ratings for a set of USA and UK banks for the sake of an increase in their market share. Also, the research will elaborate the modelling of banks credit ratings by CRA's and previous literatures. Moreover, this research will also analyze the impact of financial crisis and the adjustment made by CRA's on their ratings standards on their market share. The required information will be collected by using secondary sources on banks credit ratings.

\subsection{Research Objective}

The objective of this research demonstrates the aims and can be set down as:

$>$ To identify the quality ratings assigned by CRA's to a set of banks from UK and USA for period (2006-2018).

$>$ To categorize these ratings according to their quality grading's and on yearly basis both.

$>$ To analyze the market share of each CRA on the basis of quality and quantity ratings assigned.

$>$ To discuss the modelling of banks credit ratings and the effects of financial crisis period on CRA's market share.

$>$ To argue the adjustment in rating standards by CRA's and their effects on percentage of investment grade ratings assigned as compare to their market share.

$>$ To draw conclusion of the basis of these findings regarding percentage of investment grade ratings and market share relationship.

\subsection{Research Question}

For the sake of achieving the aims of this research the following questions must be answered.

$>$ Is the credit ratings agency market share is driven by the percentage of investment grade ratings given?

Dhat is relation between quality ratings assigned and market share of CRA's?

$>$ What is impact of financial crisis period on CRA's market share and methods for modeling of banks credit ratings?

What are effects of alterations in rating standards on CRA's market share and in number of ratings assigned?

\subsection{Report Structure}

This report comprises five major chapters which comprise sub-chapters each and the chapters are as follow:

1. Introduction describes the background of the study and reasons for following up this research. Moreover, this section explains the aims, objectives and scope of this research. Likewise, for better understanding research questions are developed which needs to be answer for achieving the required aims.

2. Literature review explains the relationship between investment grade ratings and CRA's market share. Also, it will review the modeling of banks credit ratings and effects of financial crisis on the banks credit ratings which result adjustment in their ratings standards causing an impact on CRA's market share.

3. Methodology identifies the methodology used in this research by focusing on research approach and choice. Additionally, data collection techniques and analysis will be discussed.

4. Data Analysis and Discussion shows the general analysis and detailed analysis using econometrics by using graphs \& tables. Moreover, discussion focuses on analysis of results in the light of literature review which includes the comparison between percentage of investment grade ratings assigned and an increase in market share of CRA's.

5. Conclusion reflects the summary of key results of this study and point out some limitations which reflects the problems experienced in this research project. 


\section{Literature Review}

\subsection{Chapter's introduction}

In this chapter credit rating agencies (CRA's) behavior are discussed with respect to their generosity in assigning the high-quality credit ratings to banks with the desire of increasing their market share. The role of CRA's in previous studies in assigning percentage of investment grade rating and an environment of competition between them will be explained. Additionally, the modelling of bank ratings will also be discussed which will help to acknowledge the upcoming chapters of this report. Finally, the impacts of global financial crisis on banks ratings and alteration made by the CRA's in their criteria's by assigning the ratings to different banks will be inspected.

\subsection{Credit Ratings agencies and Market Share}

The behavior of CRA's is an important factor for assigning the high-quality credit ratings for different financial institutions. CRA's could be more generous in assigning investment grade ratings for the sake of increasing their market share which can detract the investors. Four days earlier to declaration of Enron bankruptcy, majority of the CRA's were valued its debt as "Investment grade" a satisfactory investment opportunity for conventional investors (Hill 2004) which means that investors can rely on that information and can invest in that company. Furthermore, a survey carried out by Graham and Harvey (2001) shows that investors are only willing to invest in the securities which have investment grade ratings. So, it can be said that quality ratings and investor behaviors have a positive relation which may affect the investment of any organization or country level such a favorable credit rating might be a source of fascinating the foreign direct investments. On the other hand, According to The Guardian (2012), the risk of downgrade of ratings for UK and USA the negative stance of Moody's is not a serious thing because FTSE 100 was affected a little due to this. This shows that the credit ratings don't influence the investors behavior but it's an argument which can be wrong based on the evidences provided. Hence, for suitable operation of financial system requires a related quality ratings.

If we examine the market share of CRA's, according to UK Government Actuary's Department that the credit rating is an extremely intensive industry and "Big Three" collectively controlling around $95 \%$ of the business ratings. In this S\&P and Moody's having a control on 40\% each in global market. Whereas, Fitch is having $15 \%$ and others having 5\% control on global market (Investment News 2018). Furthermore, as stated by US Exchange commission (2016), the revenue reported by NRSRO's for the year 2016 is approximately $\$ 5.9$ billion which was higher than 2015 reported revenue by $\$ 100$ million.

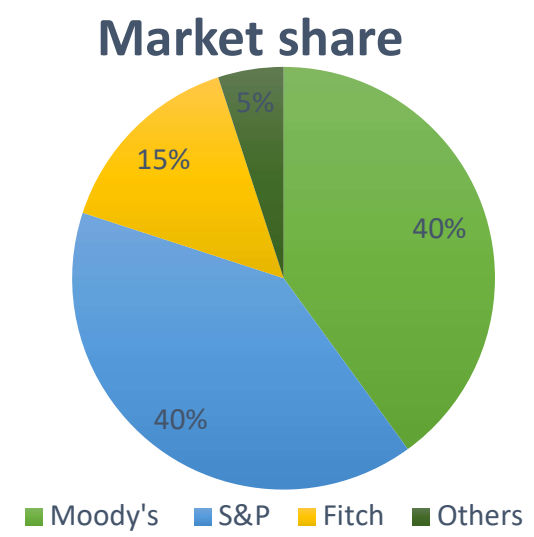

Figure 1. Industry Market Share of CRA's according to Investment News

Source: by author.

As from the figure 1, the big three almost holding the majority market share from credit rating industry and they are acting as key players in the market. As we know that market share of CRA's is dependent on size of firm and number of clients. So, they cannot afford to lose their significant market position and they might ignore their ratings standards. If we take a look towards Big three's annual reports of 2016 which clearly shows growth in revenues for fiscal years. Moody's accredited their revenues by $2 \%$ in 2016 as compared to previous years by increase ratings for bank loans, corporate debts and public finance instruments for taking 
new fee initiatives and increasing in pricing strategies. Whereas, S\&P reported $4 \%$ increase in their revenues in 2016 by increasing credit ratings for US banks loans, corporate bond ratings and some additional fees to customers. Also, Fitch disclosed their increase in revenues in 2016 comparing to pervious year by assigning higher credit ratings insurance companies and providing Fitch credit opinions.

There are a very a smaller number of studies which focus on market share of CRA's with regards to high quality ratings or IG grades assigned. However, there is a growth in market share of CRA's due to assigning more generously credit ratings to firm (Cohen and Manuszak 2013). They reflect the correlation among CRA's rivalry and the mortgage-backed securities (CMBS) by modeling the statistics of credit ratings by CRA's before financial crisis with their market share. They found a significant increase in market share of Fitch due to assigning high number of ratings as compare to its competitors. But the new entrant in the industry also affect the market share of CRA's. As Flynn and Ghent (2016) examine the entry of new CRA in designed finance products and impacts of getting higher fee from clients on their market share. They found that market share of CRA's shows an increase as the new entrants in the industry with the high effect of assigning more generously credit ratings to firms. In line with that mostly the CRA's have their performance measurement criteria's based on number of quality ratings assigned which might leads them to ignore their ratings standards for the sake of increasing their market share. Such as Bheemanaguda and Madegowda (2010) appraise the performance for credit ratings agencies in India which reveal that significant rise in credit ratings for businesses due to maximum percentage of IG credit ratings assigned. Also, for increasing their market share CRA's adopted complex models to avoid frequent downgrades for firms. All above mentioned studies emphasis on growth of market share with respect to high number ratings assigned but there are other factors which might have a significant impact on market share of CRA's such as competition, conflict of interest and reputational concerns.

\subsubsection{Market share and Conflict of Interest}

The CRA's have inherent conflict of interests in case of assigning investment grade ratings to clients. As claimed by William Harrington (former senior president at Moody's) that "Rating agencies suffer conflict of interest because Moody's uses a long-standing culture of intimidation and harassment to persuade the analyst to guarantee ratings match those wanted by the company's client" (Neate 2011). In literature, we can find examples of these type of cases in which ratings agencies surpasses their standards for the sake of increasing their market share. Faltin-Traeger et al. (2010) analyze the CRA's market share with relation to firms on the basis of favorable ratings assignment in early years which shows the importance of firm to CRA's with respect to its market share and more probability of charging the lower ratings in case of switching their services. Additionally, Bolton et al. (2012) models the competition between CRA's with some causes of conflicts which are struggle behind the understanding risk to fascinate new business and the capacity of issuer to acquire maximum positive ratings. These models result in a reduction in efficiency due to increase in competition acting as a major increase in number of ratings assigned.

\subsubsection{Market share and Competition}

However, the environment of competition on credit ratings assigned between CRAs causing an impact on their market share. Becker and Milbourn (2011) evaluates the impact of the competition on the quality of the rating and they suggested that due to increase in market share of Fitch caused the relaxing in some industries. They observe that with the increase of one-standard deviation in market share of Fitch, there is increase of 5\% to $10 \%$ in one rating level for average firm ratings. Moreover, they determined that improves rivalry from Fitch accords with lower quality ratings and level of credit ratings inversely related to the market-implied returns with a same effect with worsened the capacity of ratings. Furthermore, Camanho et al. (2010) studied the market share of CRA's with respect to current fee on basis of number of ratings and reputation. They found that a reduction in inflated ratings due to increase competition effect because CRA's have charged a high fee to become market leader. Also, they assume that issuers need a good rating to finance their project that why they have divided the credit ratings in two type which are honest and strategic by CRA's. However, honest credit ratings mean that quality of project is identified and issue a credit rating based on that. While, the strategic credit ratings are issued only to increase the profit margin by assigning higher ratings.

\subsubsection{Reputational Concerns of CRA's}

CRA's are also concern about their reputation instead of increasing their market share by assigning lower quality ratings. As, Moody's chief executive officer Raymond W. McDaniel that "we are in a business where reputational capital is more important". Moreover, he stated that "we were taking steps to manage the conflict 
of interest by improving the quality of rating assigned and protecting independence of opinions through enhancing transparency" (The New York Times 2009). There also some studies with focus on the reputation of CRA's rather than giving investment grade ratings. As, Hirth (2014) inspected the effects of competition between CRA's on credit ratings quality. They viewed that CRA's don't assign inflated firm's ratings at the expense of their reputation and they used market share of Fitch to analyze the extent of competition between CRA's. They discovered that there is no relation between market share of Fitch and ratings proposing that rivalry does not lead to ratings inflation.

\subsection{Modelling of Bank Ratings}

CRA's works under two business models which have inherent conflicts of interest. First, "Issuer-pay" model in which CRA's assigned more favorable ratings in order to hold the issuers as client and fascinating more issuers by giving higher ratings according to structured finance products. Second, the "Subscriber-pay" model in which for accessing its credit ratings the investors must pay CRA's a subscription fee (Securities and Exchange Commission 2017). The CRA's have switch to issuer pay model which results in greater transparency and higher quality ratings for high fee payment. Nowadays, CRA's are using issuer-pay model to produce returns in which issuers backing the ratings whereas only a few uses investors-pay model for their business. As Stanford et al. (2012) analyses the effects of S\&P credit ratings swapping to issuer-pay model for analysis of economic influence on ratings. They found that $S \& P$ allocated greater ratings for bonds after switching its model and these results follow greater quality in exchange for greater fee.

On other hand, if we look at credit ratings prediction models which may concern many market followers because they need to estimate these models before entering any market. Also, it is highlighted in Financial Crisis Inquiry Report (2011) that CRAs used incorrect models before the crisis for rating the designed products by banks just for sake of enhancing their market share. Moreover, Farhi et al. (2010) reviewed the opinion of CRA's in assigning the generously ratings to firms with respect to transparency of their authorizations. They argued that firms may face different CRA's and suffer their criteria's that why CRA's give more ratings to firms for the sake of increasing in their market share. There are commonly two models used by experts such as ordered probit or logit and linear regression models (Moody's investors' service 2006). These models also, covers financial metrics such as return on assets (ROA), leverage (LV), revenue stability (RS), volatility adjusted leverage (vLV) and coverage (CV). For reliability in results for credit metrics, CRA's use OLS or probit models that are vital in these modeling because they account for the asset level and coverage ratio.

Packer and Tarashev (2011) accounted the CRA's ratings approach for banks by assessing their creditworthiness and they execute suggested practices used by CRA's in their reports by separating the banks ratings into three categories. In figure 2, Stand-Alone assessment of banks illustrate their intrinsic financial strength which shows their probability of default by demonstrating their fundamental strength. For this Fitch emphasis finance, liquidity risk and balance sheet assurances, while Moody's focus on the appraisal of banks capital ratios depending on their estimated losses and S\&P highlights the growth of wealth from revenues of banks by checking their capacity and performance. While All-in ratings express the external support that banks receive in case of financial stress from different sources (As parent companies, subsidies etc.) and for these agencies mostly used a combined default analysis of banks \& funding suppliers. Moreover, System-wide assessment displays the country specific ratings used by CRA's which includes different factors such as macro indicators, industry \& governing situation and average banks ratings. There are roughly major changes done by CRA's in ratings methodologies of banks like systematic risk breakdown and earning to capital relationship.

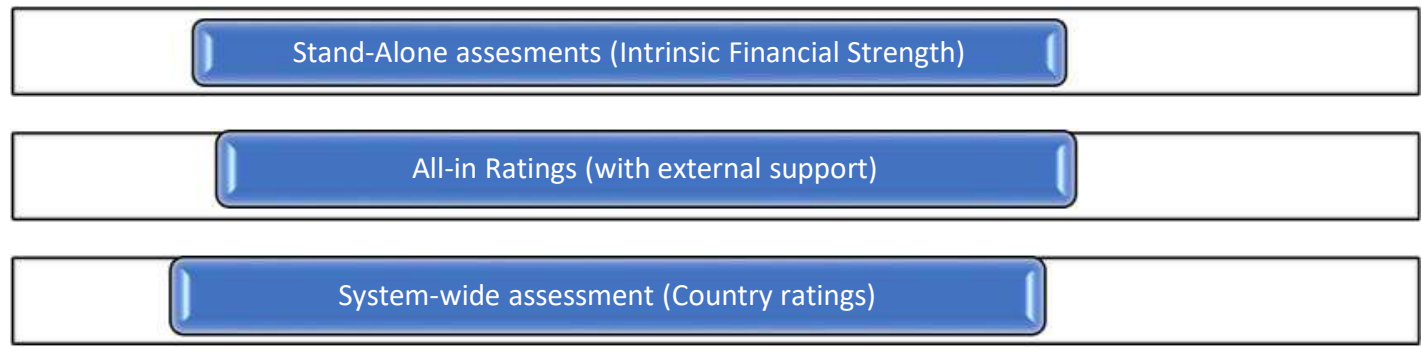

Figure 2. Methods for Banks Credit Ratings

Source: by author. 
The World Bank recognizes the ratings criteria's by CRA's using S\&P standard platform and present different factors which agencies consider while assigning ratings to banks (Katz et al. 2009). In figure 3, the ratings factors are displayed for banks in which firstly, Business risk assessment take place means to find the chances of failure for a business comprises different factors such as economic risk, industry risk, market position and diversification. Secondly, the CRA's consider financial risk assessment means to find the possibility of making financial losses due to its inadequate financial decisions which comprises financial reporting \& accounting analysis, Earnings of business, financial flexibility and capitalization of banks. Thirdly, the CRA's evaluates the enterprise risk management for banks which aims to analyze any significant danger or disaster to business that are not aligned with company's processes and goals comprises market risk, interest rate risk, liquidity risk and funding risk. After that financial, business and enterprise risks are accumulating together and issue an overall rating for that financial institution.

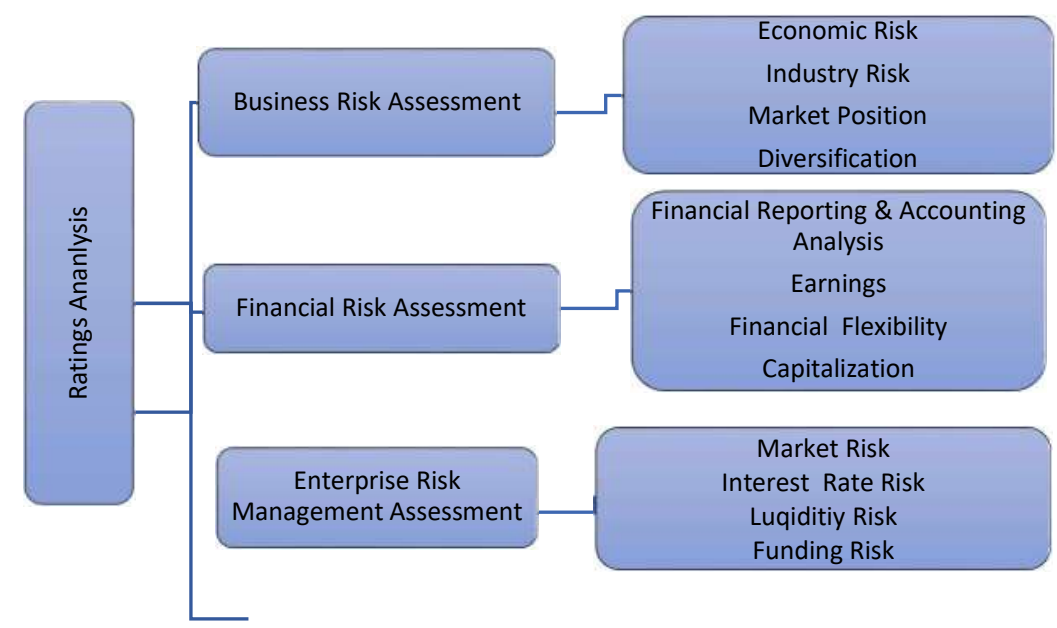

Figure 3. Factors incorporated during Ratings Analysis

Source: by author.

There are few studies in the literature which focus on the modelling of credit ratings for banks. Due to financial crisis, credit ratings become a key area and a lot of regulations came through to challenge the methodologies and modelling using by CRA's. Credit ratings become an important factor of the economies and before that we find a few studies which focus on the modelling and prediction of bank ratings. Morgan (2002) represents and analyze the bank ratings by applying of logit and probit models, in this way he become able to find factors that elaborates the inconsistency among the CRAs when they assign ratings to financial institutions. The findings represent that these inconsistencies are due to lack of clearness in financial statements of banks. There are also other studies which shows the difference between countries regarding bank ratings. Iannotta et al. (2008) examine the impacts for holding structure of banks on Fitch and Standard \& Poor's ratings in European Union and found out that public holding banks gain higher rating than other banks. Similarly, Peresetsky et al. (2011) used an ordered logit model to determine the causal factors of Moody's foreign currency long-term Deposit Rating (DR) and Banks Financial Strength Rating (BFSR) and reveals that Moody's incorporating not only internal factors but external factors also like political risk. Bellotti et al. (2011) concluded that there are different factors effects the banks ratings according to country specific conditions by using logit and Support Vector Machine models. Whereas, old EU countries gained higher ratings as compare to new EU member countries (Caporale et al. 2011). Furthermore, Ögüt et al. (2012) emphasis on modelling the CRA's Banks Financial Strength ratings for Turkey set of banks and found out that predictions are consistent with the index depending on environmental variables.

\subsection{Impacts on Market Share due to Financial Crisis and Alterations in Ratings Standards}

The global financial crisis was initiated by a few numbers of well-known monetary institutions which have global importance. But many smaller USA based banks and thrifts also collapse in the period of financial crisis and adding their names in the FDIC's list of failed organizations (DeYoung and Torna 2013). The dawn of subprime mortgage crisis in 2007 which followed by the sovereign debt crisis in Europe have increased the uncertainty about the performance of the three key rating agencies (Fitch, Moody's and Standard \& Poor's) and value standard of the ratings issued. Especially, credit rating agencies (CRAs) were blamed for easing their rating criteria during the economic expansion time until the mortgage crisis erupted (Securities and Exchange Commission 2008). Agencies were also condemned for the conflicts of interest that appear from 
their business model, the deficiency of clearness and the lavish trustworthiness of investors and regulators (Bank of England 2011). There is also incapacity to value the risk relevant to Asian financial crisis in 1997 and in the failure of Enron and Parmalat at the start of the century. In the light of this, there are several reforms carried out in USA in which the Customer Protection Act 2010 and the Dodd-Frank Wall Street reforms are major one for implementing the restrictions on the CRAs to protect the conflict of interest and increase transparency. Moreover, the Basel committee appraised the part of ratings in the computation of regulatory capital requirements (Sundmacher and Ellis 2011). In reply for this condemnation, CRAs have secured them by saying that their rating standards are based on medium and long-term probabilities (Through-The-Cycle) and accordingly failed to consider the short-term changes causing the solvency of the product that they value. So, there is a lack of Point-In-Time outlook regarding issuance of ratings (Salvador et al. 2018). Therefore, rating agencies toughen their standards which cause a general downfall in ratings and this fall had further aggravated the economic condition because as many governments and companies that had suffered economic difficulties which results in significant hardening of conditions for access to capital markets (Balland et al. 2011).

However, Shen et al. (2012) conclude that there are main differences arises in credit ratings due to unbalanced information across the banking system and this have done on sample of Standard and Poor's rated banks to find the differences in credit ratings among countries by keeping financial variables constant. Similarly, Salvador et al. (2014) analyze the effects of financial crisis on Spanish banking system by using profit model and found that average banks rating fall by $13 \%$. In addition to that Salvador et al. (2017) analyze the impact of financial crisis for set of banks around the world, they found that a major fall in ratings due to this event and in that Fitch, Moody's and S\&P shows a fall in ratings $8.75 \%, 8.17 \%$ and $15.94 \%$ respectively which results due to hardening the rating standards and policies. Furthermore, Pastor et al. (2017) examine USA, EU and Japanese banks rating and adjustments made in its due crisis and they analyses also the crisis effects with respect to bank assets. CRA's have made an arrangement with the New York State Attorney General Andrew Cuomo for altering some criteria of ratings allocation which particularly emphasis on avoiding the issuers for payment regarding precise ratings and compelling them to pay an initial fee before performing any investigation (Lucchetti 2008). By seeing all these arguments, it is clear that due financial crisis and adjustment in ratings criteria's of CRA's cause a significant fall in ratings which results in reduction of their market share.

Overall, in the light of these studies CRA's are holding significant part of industry and played an important role in the decision-making process. All these studies discussed above focus on different factors such as reputation, competition between CRA's effect the credit ratings and their market share. Moreover, modeling of banks ratings is considered important in decision making process for investors and the business model discussed have also key factor in assigning the number of ratings by CRA's. In addition to that effect of financial crisis and adjustment in ratings criteria triggered a significant reduction in number of ratings assigned by CRA's which results a fall in their market share. But these studies didn't talk about specifically the percentage of IG grade ratings and effect on market share which raise the question of our research which we are going to examine that the generosity in assigning the percentage of IG influence the market share of CRA's. So, in this research we will investigate this relationship in the light of these studies and analyze our findings for creation of new ideas for better understanding of literature.

\subsection{Chapter's Conclusion}

The chapter conclude that relying on the discussion it can be indicated that part of CRA's is very vital in the economic system especially for investors in decision making process and big three act as key players in market. CRA's might concern of different factors such as reputation, competition and business model regarding assigning higher ratings to banks. Moreover, due financial crisis the CRA's have hardener their standards which results in significant fall in quality ratings which might impacts their market share. We will study the generosity of CRA's in assigning high percentage of IG just for the sake of increasing their market share for a set of banks.

\section{Methodology}

\subsection{Chapter's Introduction}

In this chapter, the motive of research will be discussed in detail as mentioned in first chapter for the purpose of better acknowledgement of key requirements. Moreover, the theoretical methodologies that can be applied 
will be described briefly and the chosen methodology will be discussed thoroughly which later connected with the details of this research. This will allow to interpret the existing issues in using these methods and resolving them. Also, the data collection techniques will be elaborated and verification of ethics implementation for this research will be provided. At the end, a methodology will be developed by using all the techniques discussed which will help in the progress of this research.

\subsection{Research Methodology Overview}

For answering the research questions, we need to select an appropriate research methodology. Research methodology comprises a suitable research approach, strategy \& philosophy, choice for the achievement of our research aims and objectives. The key question of this research is to analyze the change in market share of CRA's due percentage change investment grade of ratings assigned each year. For making a discussion on research methodology we will follow Saunders, Lewis and Thornhill (2009) proposed research onion model which consist on different layers. The research philosophy is to indicate the researcher views about this world. The research approach can be deductive or inductive and this will answer all questions of this research. The meet the objective of this project, research strategy will be designed by incorporating different choices. Later on, data collection techniques will be discussed and based on this analysis methods will be elaborated.

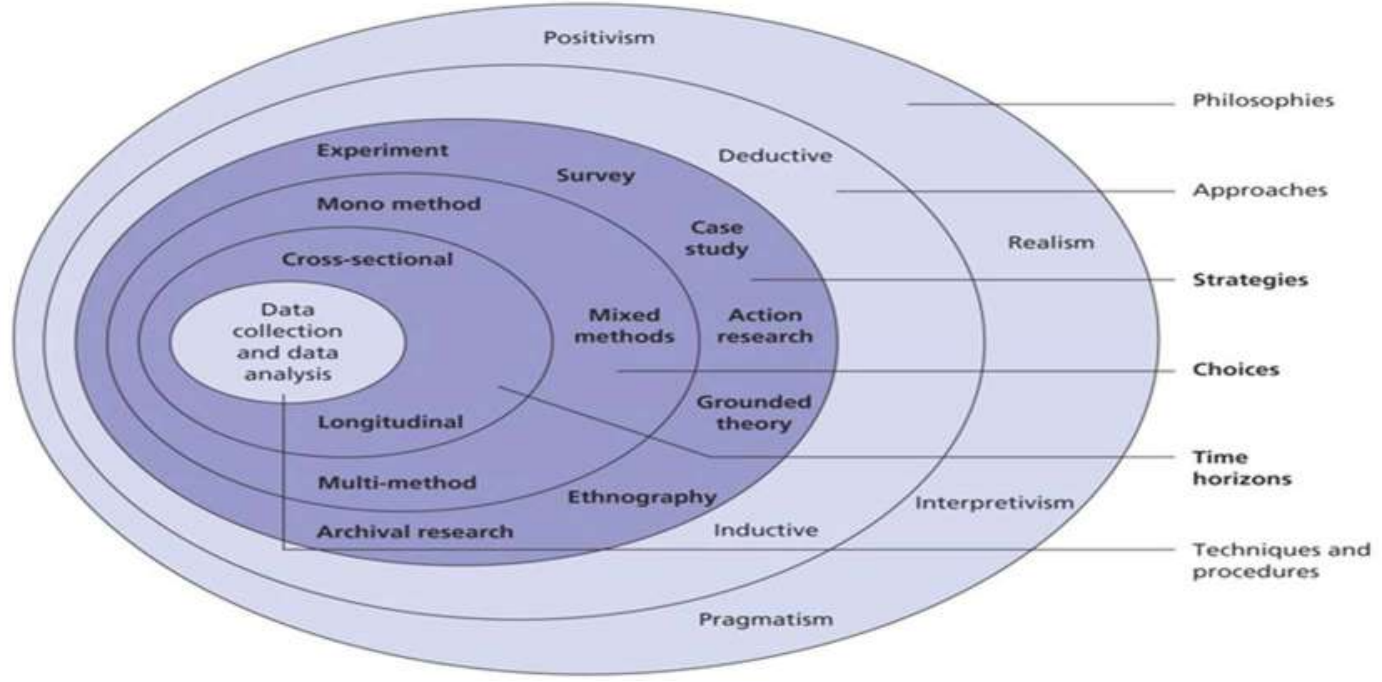

Figure 4. Saunders Onion (2009)

Source: by author.

\subsection{Research Philosophy:}

Research philosophy is a method of contentions about paradigm to improve knowledge (Saunders et al. 2009). The aspects of research paradigm are given below:

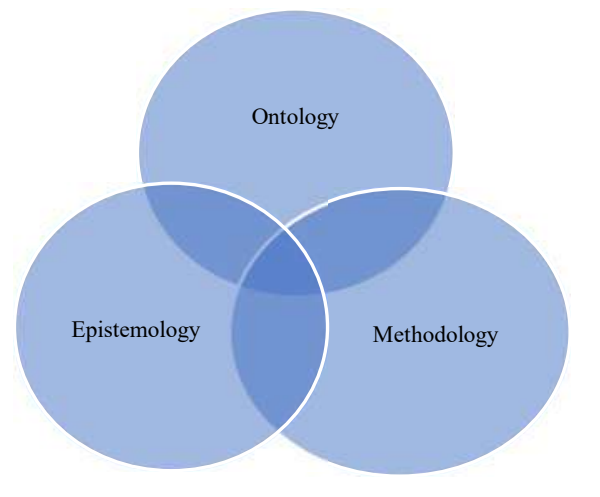

Source: by author.

Figure 5. Aspects of Research Paradigm

Easterby-Smith et al. (2012) elaborates the research philosophy into three paradigm which define as follow. Ontology is the philosophical assumptions around the nature of realism. In ontology, the researcher argument around the realism (fact is present and can be exposed) and relativism (facts depends on perspective of spectator) because talk about single truth, but relativism say that there are many truths. Whereas, Epistemology 
is an overall set of suppositions around the ways of probing into the nature of world and creation of association between researcher and reality. This is consisting on positivism (actual knowledge derived from thought), interpretivism (recognize and understands the meanings) and realism for continuing a research work. In addition to that, Methodology is the method to investigate into a particular situation by using diverse techniques. The figure 5, demonstrate the relation among three research paradigms for carrying on particular research because they are inter-reliant on each other like if one take ontology will impact one's epistemology and this varies around the research studies. Considering Saunders onion, research philosophy is divided in to different sub headings which are positivism, realism, interpretivism and pragmatism. While, the pragmatism is position where they can accept the preset ideas which shape the knowledge. However, the positivism is a technique in which researcher belief that social reality is stable, and he must develop research questions that can be examined which permits clarification about the knowledge in which we live. This condition forms a structure of research that can be reproduced by other researchers to create the identical outcomes. The priorities will be on quantifiable outcomes that accord themselves to statistical analysis. The positivistic philosophy will be used in this research because it will allow to analyze the market share of the CRA's based on percentage of IG ratings assigned by them. Moreover, this will help to answers the research questions by verifying the result outcomes in line with the previous literatures.

\subsection{Research Approach:}

Research approach is method in which aims \& objectives of the progressive research will be identified and select a suitable method for current research. There are two techniques recommended by Saunders in his research onion.

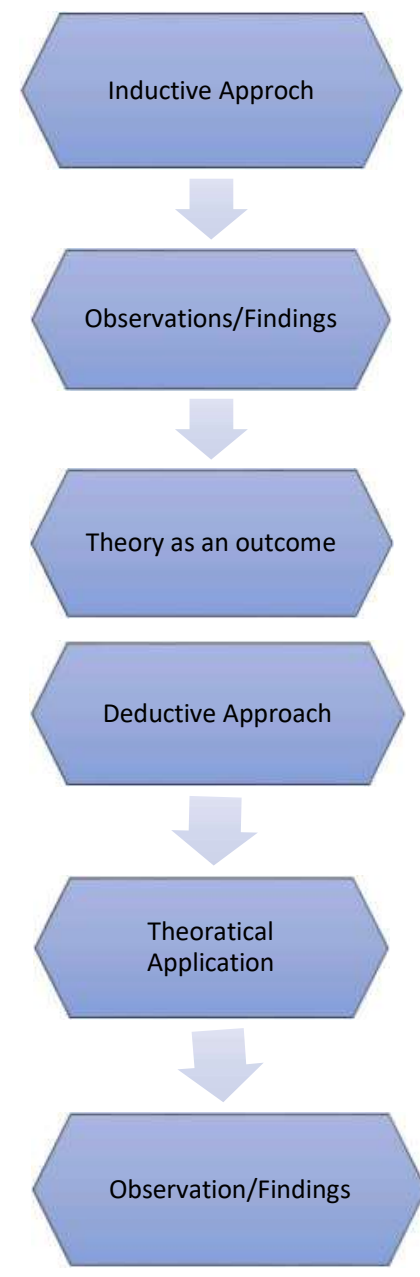

Source: by author.

Figure 6. Research Approaches and their Outcomes

Firstly, Inductive approach is based on the reasoning to develop new theory from observations by using the hypothesis. Additionally, this approach starts with the conducting of observations which lead to the development of new theories following the relevant hypothesis. Secondly, deductive approach comprises to 
justify the credibility of assumptions and indicate the most common view of link between theory and research (Bryman and Bell, 2011). This approach consists on the generation of a hypothesis from a previously existed theory and for testing this a researcher plan a research strategy by confirming the rationality of these theories in given situations. In this research, deductive approach will be used which allows to construct a hypothesis that needs to be accept or reject during research process because we can explore current models and attempt to validate them in our research context. This will be prepared by taking a common information regarding credit ratings agencies, their modelling for bank and their market share. Also, this will allow to analyze the credit ratings secondary data collected for a set of banks from UK and USA with respect to CRA's market share. Furthermore, results will show the reliance of market share on generosity or quality credit ratings assigned by CRA's.

\subsection{Research Strategy}

Research strategy is the process by which data will collected and analyze because this is vital when conducting any research work for describing the connection among the research question and theory. This is related to the general research approach taken into attention and implemented throughout inquiry. There are different research strategies recommended by Saunders in his research onion such as experiments, surveys, case study and ethnography Etc. In this research, experiment strategy is used to analyze whether the change in independent variable effect change in dependent variable such as market share is dependent variable upon the percentage of IG of ratings assigned by CRA's using econometrics analysis. The secondary data is collected by using Fitch-Connect and then following literature we will make a comparison with market share. We will follow the approach regarding modelling and analysis of bank credit ratings as described in Moody's investor services report (2006) using linear regression model. Moreover, further analysis will be made using general comparison between market shares in accordance with the number of IG ratings.

\subsection{Research Choice}

According to Saunders research onion, there are various techniques by which data can be collected for the sake of obtaining the desire research objectives. At this stage, researcher must choose the data gathering method by Qualitative (using quantity and measurement) or Quantitative approach (using opinions and description) or both. The techniques used for research choices is mono method, mixed method and multi method. In this research, Mono method will be used which allows to choose quantitative or qualitative method can be used rather than mixed method. The quantitative approach to study the descriptive sample by calculating the features of that sample and based on that attempt the construct the overview for that sample as whole (Wilson 2014). The quantitative approach is linked with the deductive approach because the analysis done in this approach is statistical for assessing the results and follow the existed theories. While, the qualitative approach in which analysis of narrative data is carried on and this approach is associated with the inductive study. In this research, we will incorporate only quantitative approach because it only allows single approach choice. So, the quantitative data collected by using online platform Fitch-Connect.

\subsection{Research Time Horizon}

Time horizon consist on two parts as reported by Saunders research onion and that are cross-sectional and longitudinal. The cross-sectional technique is used to compute the characteristics of data at a single point of time and it is a study for short periods. This type of time horizon is applied when the time is limited for a research so just understand the collected data and draw the results. Whereas, longitudinal technique is used to analyze the data over a longer period of time, and it is a long-term study. In this research, longitudinal time horizon technique is used to analyze the data of credit ratings over last 12 years for set of banks.

\subsection{Research Data Collection Technique \& Ethics}

The research data collection techniques are related with the gathering of data from several sources that has been transformed, perceived and systematized in a proper way for continuity of research which cover two areas which are nature of collection data and its classification (Saunders et al. 2009). Firstly, the nature of collected data explains that whether it is primary or secondary data using in the study. Secondly, the classification of data elaborates about whether it is qualitative or quantitative data undertaking in the project. The primary data is gathered through primary source such as interviews, surveys, questionnaires etc. and transformed according to specific research strategy. However, the secondary data that are collected secondary source such as books, journals, internet etc. and converted into sensible form for analysis of research. In classification of data, the qualitative data represents the non-numerical data which indicates the views, conduct and attitude of anything and can be collected by primary sources. While, the quantitative data represents the 
numerical data which specifies the numbers in the data. In this research, the nature of collected is classified as secondary data and collected by online platforms Fitch-Connect using internet. Also, in this research quantitative approach is used for data analysis. As for concern of data reliability, the data collected by using online sources which can be trusted and reliable. In addition to that, this is secondary data so, there are no ethical consequences and permitted by university. Moreover, the reliability of this research is indicated that the outcomes can be obtained numerous times via same methodology (Easterby-Smith et al. 2014). By using specific research methodology results can be obtained and that indicated the research validity which is an important factor in research work. In this research work, the methodology followed is highly valid and can be reliable because used of authentic reports and journals recommended by CRA's.

Lastly, the ethical consideration is a central part of the research because without that the research is not valid and can't be proceeded. According to Braymen and Bell (2011) ethical recommendations are considered such as research confidentiality is confirmed, researcher is not subjected to any harm during his project and dignity of the research is prioritized. Moreover, the work of previous researcher used must be acknowledge by giving proper reference. In this research all these factors are especially taken care off because of making research work more worthwhile.

\subsubsection{Sample}

The sample holds 21 banks of UK and USA for which credit ratings are acquired using Fitch-Connect platform and three main CRA's are used which Moody's, Fitch and S\&P. The credit ratings used in this research are "Long-term issuer Default Ratings" (IDR) because that represents an enhanced indicator for firm's performance (Salvador \& Pastor 2018). This type of ratings is known as issuer ratings which indicates the credit excellence of the issuer appraised by these CRA's. This research covers the period from 2006 to 2018 because to capture a superior depiction of market share of CRA's in accordance with time.

\subsection{Chapter's Conclusion}

The chapter concludes that the methodology chosen for this research to achieve the objectives. The research philosophy used in this study is positivism and deductive research approach is used. Moreover, the research strategy used in this research is experiments and the research choice is quantitative approach. The data is collected by secondary sources and the time horizon of 12 years is used following the longitudinal approach. By using these techniques, aims and objectives of this research are achieved and developing better understanding.

\section{Data Analysis and Discussion}

\subsection{Chapter's Introduction}

This section will tell us about the key findings of this research so that a better understanding can be developed. After understanding of credit ratings in literature review section and using the methodology of previous section which are the roots of this research the following results are generated. The data is consisted on two parts. Firstly, methods of data representation will be analyzed by making comparison between markets shares of CRA's through graphical representations. Later on, market share, growth rate analysis and generation of research tools will be reviewed. Also, the detail analysis consists on econometrics models and graphs. All the models and graphs are created by using econometrics software "GRETL". Secondly, general comparisons will be seen which consisted on graphs and tables (shown in appendix) are created by using excel.

\subsection{Data Analysis}

In order to develop the require research tool for this project, data collected by online sources (secondary data) by using quantitative approach and the technique used to analyze this data is by experiments. The collected data transformed into tables and graphs which are presented in analysis section and the tables presented in the appendix. In order to analysis of data two separate techniques have been used for better understandings of results which are listed below.

\subsubsection{General Analysis}

In general analysis, the data is transformed into different tables by using excel which are presented in appendix and using these tables graphs have been transformed. In this analysis, we assess the market share through percentage of investment grade ratings assigned by CRA's for each set of banks. The categorical scale 
converted into a numerical scale 10 which defines that higher value for higher quality ratings (Caporale et al. 2011). In this research, only investment grade ratings are analyzed that why due small ratings we only use scale 10. Moreover, market share and growth rate analysis will be analyzed on the basis of ratings assigned.

\subsubsection{Ratings Assigned}

The figure 7 represents the number ratings assigned by CRA's to each bank from 2006-2018 and these ratings include whole scale of investment grade. In this graph, Fitch is leading their competitors in assigning ratings because in total it assigned more than 390 ratings for these group of banks which cause an increase its market share. Whereas, Moody's in second number with about 182 ratings and S\&P in third number with about 129 with less market share.

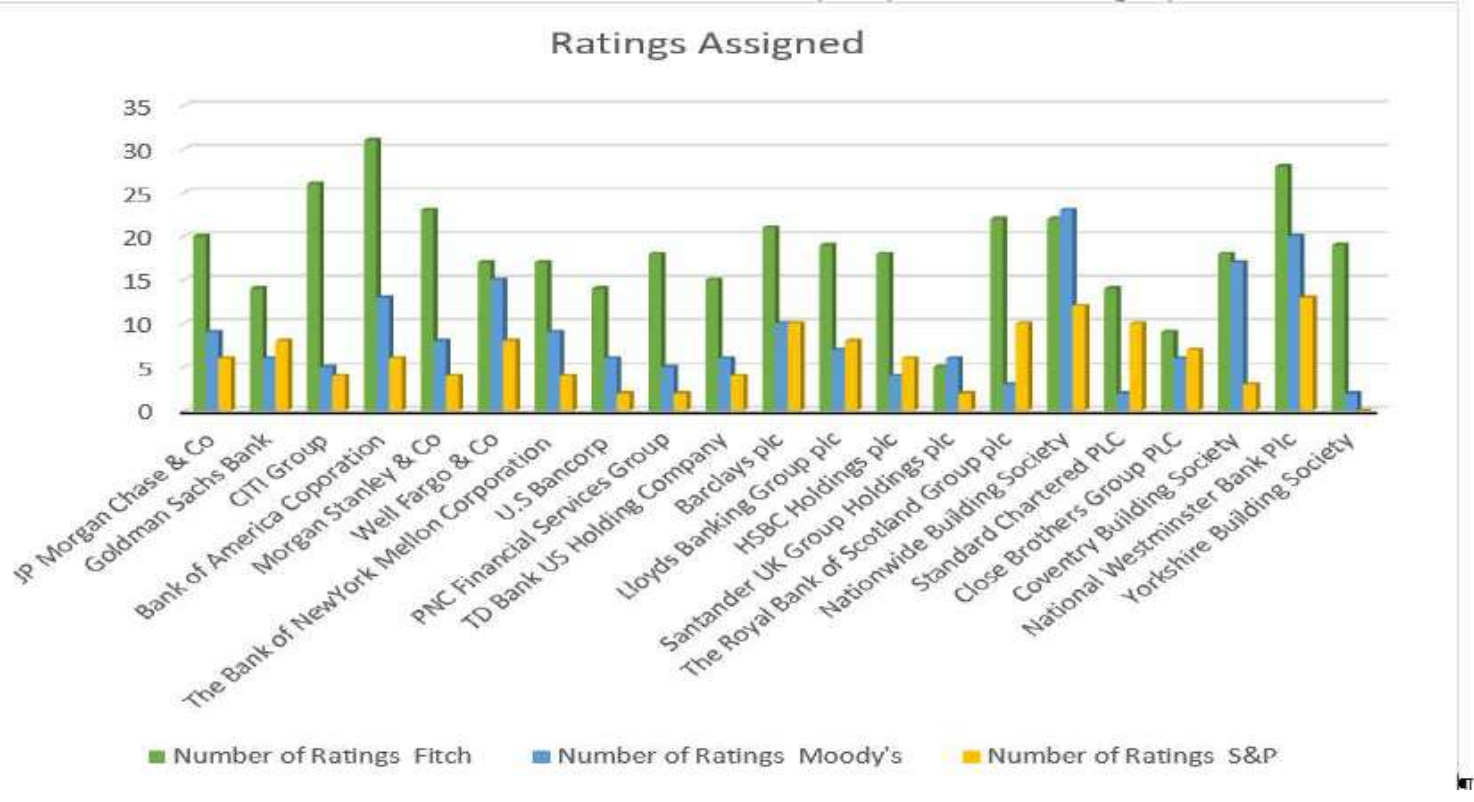

Figure 7. Number of Ratings Assigned for each Bank by CRA's

Source: by author.

\subsubsection{Grades of Ratings}

The figure 8 shows the quality of ratings assigned by each CRA's. Fitch assigned more AA-, A and A+ ratings for banks which is an indicator of quality ratings given and leading its competitors. So, the Fitch assigned scale 10, 5 and 6 which show more high investment grade ratings which cause an increase its market share. Moody's assigned scale 10 rating which a higher quality rating in the investment grade and scale 4 ratings which cause an increase in its market share. Whereas, S\&P gives scale 7, 8 ratings that's why their market share is less than their competitors.

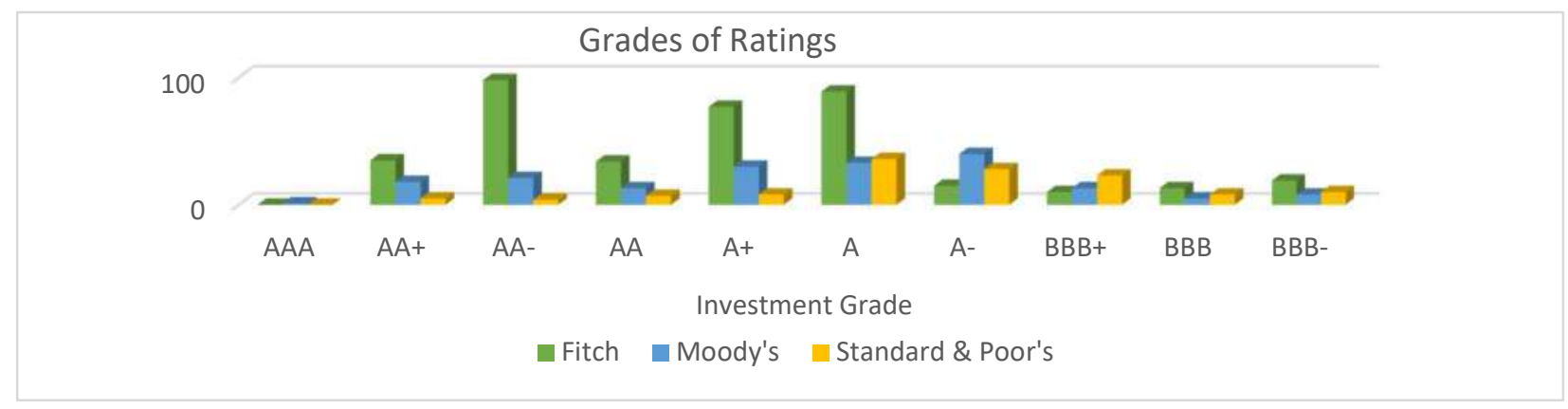

Figure 8. High quality Credit Ratings assigned by CRA's

Source: by author.

\subsubsection{Market Share Analysis}

The figure 9 shows the number of ratings assigned by big three CRA's for period 2006-2018. Whereas, figure 10 shows their respective market share comparison. As in 2006-2012, the number of ratings assigned by Fitch are higher which cause an increase in its market share for that years. On other hand, Moody's and S\&P 
assigned a smaller number of ratings but lower quality ratings in investment grade which cause a decrease in its market share. In 2013-2014, S\&P assigned more ratings than Fitch and Moody's and the market share of S\&P increases as compare its competitors. Late on its market share drop down due to less number of ratings. In 2017 Moody's grabbed higher market share due to quality and quantity of ratings assigned and there is a fall in number of ratings for Fitch in respective years causing a significant fall in market share.

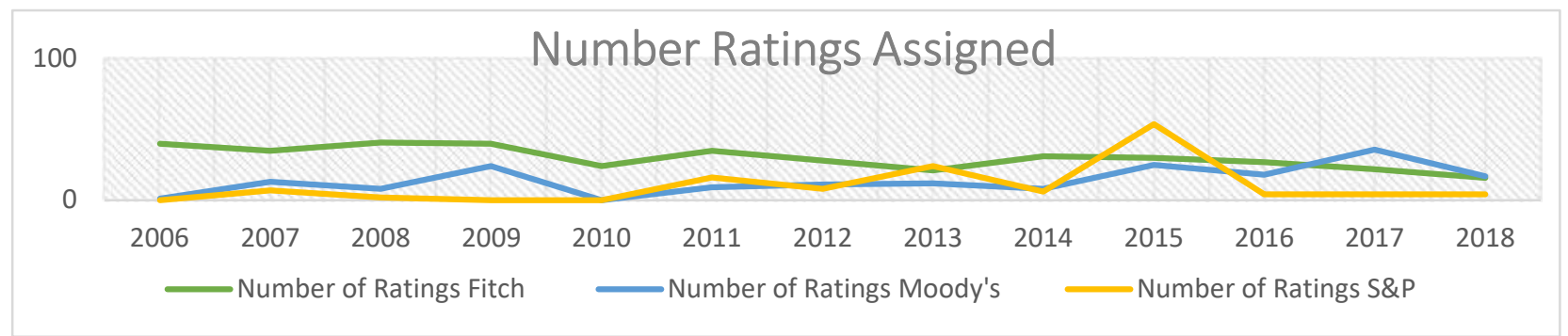

Source: by author.

Figure 9. Yearly Comparison for Number of Ratings Assigned by CRA's

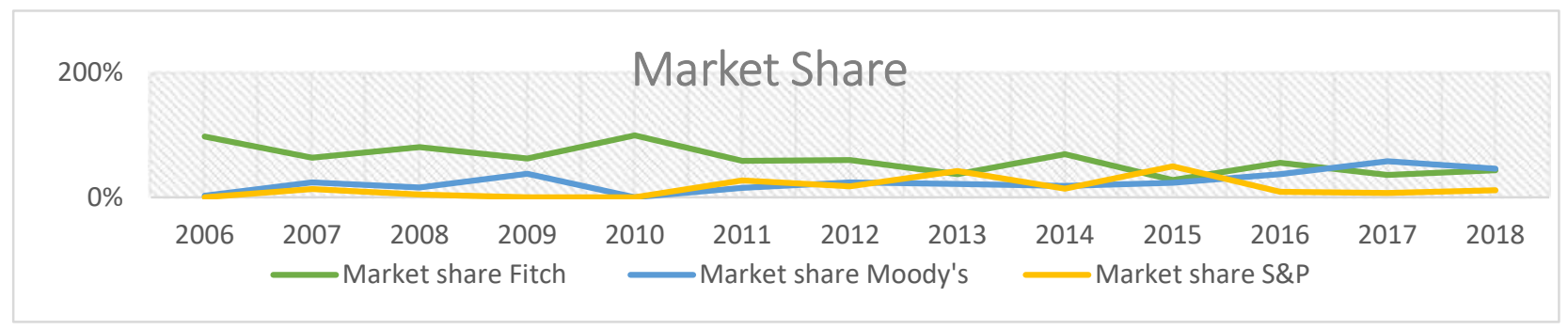

Figure 10. Yearly Market Share comparison of CRA's

Source: by author.

The figure 11 shows market share based on number ratings assigned by CRA's for period of 2006-2018. Fitch have high market share in the early years while in later years its market share dropped down. Moody's and S\&P market share is very less in early years but later on its shows an increase because after the financial crisis a lot of regulations come regarding rating agencies which cause hardening of credit ratings policies by CRA's. In total Fitch gave more generously ratings to bank and its market share is above than its competitors about $50 \%$ which is a very high number in the sector. Whereas, Moody's stayed on second number with about $25 \%$ and S\&P is at last number with about $20 \%$ ratings in the sector based on the number of ratings they have assigned.

\section{Market Share Comparison}

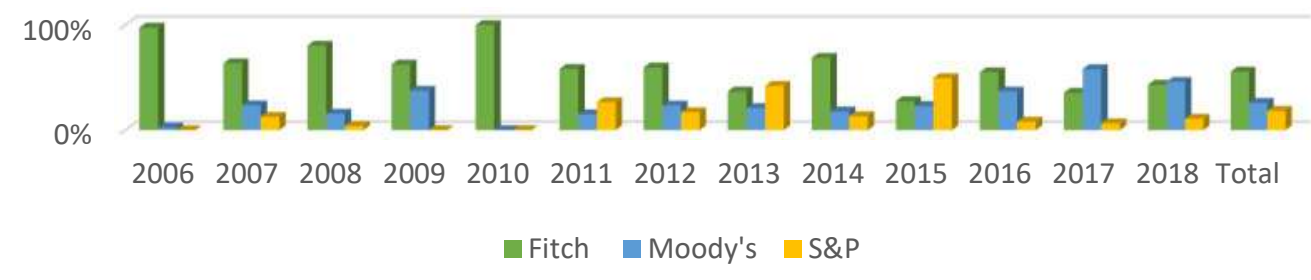

Figure 11. Yearly Market Share of CRA's comparison based on Quality Ratings assigned

Source: by author.

\subsubsection{Growth Rate Analysis:}

The figure 12 analyzes growth rate in market share of CRA's based on number of ratings assigned and this is percentage rate change as compare to its previous years. There are some abnormal changes in some years like in 2007 Moody's showed a massive in create in its market share and it assigned more ratings as compare to other ratings agencies. In the period of financial crisis, the growth rate for each CRA is was declined and after 
than S\&P remained dominant in the market. There are some years in which CRA's agencies showed negative growth as compare to previous years by assigning fewer quality ratings.

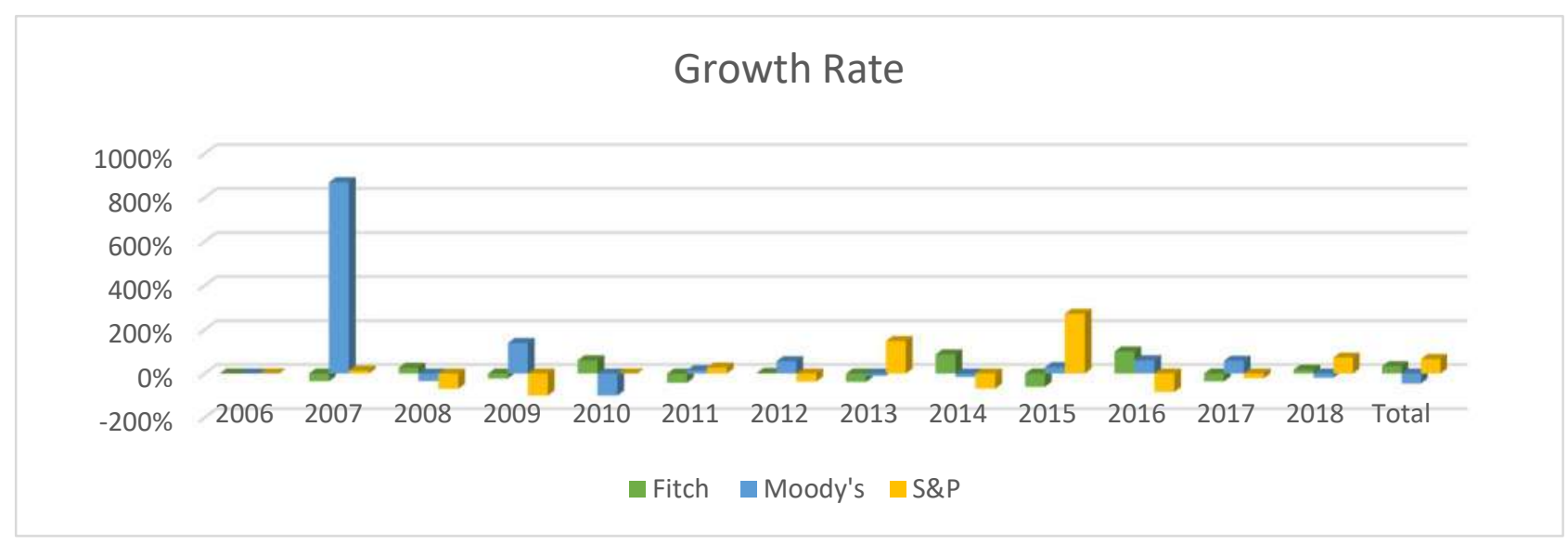

Figure 12. Growth Rate Comparison of CRA's

Source: by author.

Due to abnormal increase in growth rate in 2007, it is difficult to analyze growth rate for other years. So, the figure 13 shows growth rate from 2008-2018 based on number ratings assigned for more accurate analysis.

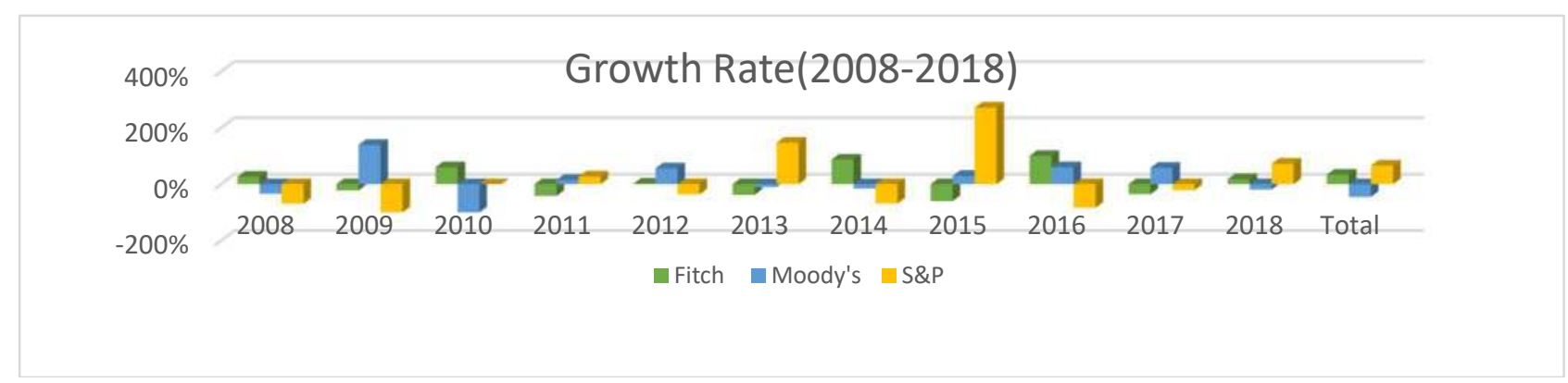

Source: by author.

Figure 13. Growth Rate Analysis of CRA's after Financial Crisis

\subsubsection{Econometrics Analysis}

An Econometrics analysis is method used to develop test hypothesis by using data sets and develop statistical \& mathematical models. Linear regression model tool has been used for the analysis of market share and number of ratings and its very useful tool for full analysis before staring of every research (Judge et al. 2002). The dependent variable for each CRA is the market share over investigation period (2006-2018). Whereas, the independent variables are percentage of Investment grade ratings assigned by CRA's to a set of banks from UK \& USA and $\varepsilon$ is standard error term. The equations developed are given below:

\section{Equation 1: Regression Equation for S\&P}

Market share $(S \& P)$

$$
\begin{aligned}
& =\mathrm{a} 1 \text { market share }(\mathrm{S} \& \mathrm{P}: \mathrm{t}-1)+\mathrm{a} 2 \text { marketshare }\left(\operatorname{Moody}^{\prime} s: t-1\right) \\
& \text { + a3 marketshare(Fitch: } \mathrm{t}-2)+\mathrm{b} 1 \text { (\%IG:S\&P:t) + b2 (\%IG: Moody's: } \mathrm{t} \text { ) } \\
& \text { + b3(\%IG: Fitch:t) + c1(\%IG:S\&P: t - 1) + c2(\%IG: Moody's: }-1) \\
& \text { + c3(\%IG: Fitch:t }-1)+ \text { d1 }(\% I G: S \& P: t-2)+d 2(\% I G: \text { Moody's: } t-2) \\
& +\mathrm{d} 3(\% \mathrm{IG}: \text { Fitch: } \mathrm{t}-2)+\varepsilon \ldots \ldots
\end{aligned}
$$

Equation 2: Regression Equation for Moody's

Market sha (Moody's)

$$
\begin{aligned}
& =\mathrm{a} 4 \text { market share }(\mathrm{S} \& \mathrm{P}: \mathrm{t}-1)+\mathrm{a} 5 \text { marketshare }(\operatorname{Moody} s: t-1) \\
& \text { + a6 marketshare(Fitch: } \mathrm{t}-2)+\mathrm{e} 1 \text { (\%IG: S\&P: t) + e2(\%IG: Moody's: } \mathrm{t} \text { ) } \\
& \text { + e3(\%IG: Fitch: t) + f1(\%IG:S\&P:t - 1) + f2(\%IG: Moody's: } t-1) \\
& \text { + f3(\%IG: Fitch: } \mathrm{t}-1)+\mathrm{g} 1(\% \mathrm{IG}: \mathrm{S} \& \mathrm{P}: \mathrm{t}-2)+\mathrm{g} 2(\% \mathrm{IG}: \text { Moody's: } \mathrm{t}-2) \\
& + \text { g3(\%IG: Fitch: } \mathrm{t}-2)+\varepsilon \ldots \ldots \ldots
\end{aligned}
$$


Financial Markets, Institutions and Risks, Volume 4, Issue 1, 2020

ISSN (online) - 2521-1242 ISSN (print) - 2521-1250

\section{Equation 3: Regression Equation for Fitch}

$$
\begin{aligned}
\text { Market sha } & \text { (Fitch) } \\
& =\mathrm{a} 7 \text { market share(S\&P: } \mathrm{t}-1)+\mathrm{a} 8 \text { marketshare }(\text { Moody's: } t-1) \\
& +\mathrm{a} 9 \text { marketshare(Fitch: } \mathrm{t}-2)+\mathrm{h} 1(\% \mathrm{IG}: \mathrm{S} \& \mathrm{P}: \mathrm{t})+\mathrm{h} 2(\% \mathrm{IG}: \text { Moody's: } \mathrm{t}) \\
& +\mathrm{h} 3(\% \mathrm{IG}: \text { Fitch: } \mathrm{t})+\mathrm{i} 1(\% \mathrm{IG}: \mathrm{S} \& \mathrm{P}: \mathrm{t}-1)+\mathrm{i} 2(\% \mathrm{IG}: \text { Moody's: } \mathrm{t}-1) \\
& +\mathrm{i} 3(\% \mathrm{IG}: \text { Fitch: } \mathrm{t}-1)+\mathrm{j} 1(\% \mathrm{IG}: \mathrm{S} \& \mathrm{P}: \mathrm{t}-2)+\mathrm{j} 2\left(\% \mathrm{IG}: \text { Moody's }_{\mathrm{t}-2)}\right. \\
& +\mathrm{j} 3(\% \mathrm{IG}: \text { Fitch: } \mathrm{t}-2)+\varepsilon \ldots \ldots \ldots
\end{aligned}
$$

Tables 1, $2 \& 3$ presents the results of the estimation of Eq. (1), (2) \& (3) which models the market share of each CRA against the percentage of IG ratings assigned. This shows the coefficients which are estimated by using standard ordinary least squares (OLS) regression method. The OLS is only effective once certain assumptions are fulfilled which are the error is "normally distributed" and dependent variable is "continuous". The dependent variables are forecasted, and independent variables are used to describe it. Commonly, the variables which represented by number of ratings given by CRA's in (2006-2018) are showing the same trend as mention in the literature review section.

Table 1 represents the simple regression analysis in which the market share of each CRA regress against the percentage of investment grade ratings given just for getting immediate effect in time period ( $\mathrm{t}$ ). In Model 1, the column 1 shows that S\&P act as a dependent variable in which for every $1 \%$ investment grade ratings given by $\mathrm{S} \& \mathrm{P}$ cause an increase in market share of S\&P by 0.009982 . This value is statistically significant which means that the coefficients are significantly different from zero at $5 \%$ level. Similarly, the fall in the market share of S\&P by 0.00179 and 0.00320 due to higher investment grade ratings by Moody's and Fitch respectively. R-squared expresses that how good the model is at fitting the data which represents the $89.31 \%$ variation in the market share of S\&P can be explained by the variations in by percentage of S\&P IG and other variables. In Column 2, Moody's market share is dependent on percentage of IG given. The market share of Moody's shows an increase by 0.01502 for every increase in $1 \%$ of IG ratings by Moody's and this value is also statistically significant at 5\%. Moreover, the R-squared explain that the $92.86 \%$ variation in the market share is explain by the Moody's and other two variables. Similarly, Fitch market share is also increase by 0.00718 in column 3 for every 1\% increase in IG ratings by Fitch. Also, the other two agencies ratings are

\begin{tabular}{|c|c|c|c|c|c|}
\hline & \multicolumn{5}{|c|}{ OLS estimates } \\
\hline & $\begin{array}{c}\text { Dependent variable: } \\
\text { SP_ms }\end{array}$ & & $\begin{array}{c}\text { Dependent variable: } \\
\text { Moodys_ms }\end{array}$ & & $\begin{array}{l}\text { Dependent variable: } \\
\text { Fitch_ms }\end{array}$ \\
\hline \multirow[t]{2}{*}{ const } & $0.1688^{*}$ & const & $0.2141 * *$ & const & $0.6171 * *$ \\
\hline & -0.08017 & & -0.06778 & & -0.1276 \\
\hline \multirow[t]{2}{*}{ SP_IG } & $0.009982 * *$ & SP_IG & $-0.003689 * *$ & SP_IG & $-0.006294 * *$ \\
\hline & -0.00121 & & -0.001022 & & -0.001923 \\
\hline \multirow[t]{2}{*}{ Moodys IG } & -0.00179 & Moodys IG & $0.01502 * *$ & Moodys IG & $-0.01323 * *$ \\
\hline & -0.001848 & & -0.001562 & & -0.00294 \\
\hline \multirow[t]{2}{*}{ Fitch IG } & -0.00320 & Fitch IG & $-0.004718 * *$ & Fitch IG & $0.007918 *$ \\
\hline & -0.00225 & & -0.001903 & & -0.003582 \\
\hline $\mathrm{n}$ & 13 & $\mathrm{n}$ & 13 & $\mathrm{n}$ & 13 \\
\hline $\mathrm{R}^{2}$ & 0.89310 & $\mathrm{R}^{2}$ & 0.9286 & $\mathrm{R}^{2}$ & 0.8646 \\
\hline
\end{tabular}
showing a negative value which means that the market share drop due their percentage of ratings given. The coefficient of Fitch is statistically significant at $10 \%$ which means that value is okay and significant different from 0 . The R-squared shows that $86.46 \%$ variations in market share explained by the independent variables respectively.

Table1. OLS Estimation based on Percentages of IG Assigned

Notes: * indicates significance at the 10 percent level; ** indicates significance at the 5 percent level.

Source: by author.

Table 2 expresses the results of OLS estimates market share of CRA's and percentage IG ratings by each CRA. In this model, market share of each CRA regress against the 1-year lag market share of CR's and percentage of their IG. The use of lag in the variables is due to find the effects of market share because if the CRA's assigned higher percentage of IG ratings than the market share went up. These consequences might not happen immediately due these effects in market share can be interpreted that why the lagged variable are suitable. Also, it is considered that market share effect by other factors like size of the firm and nature of clients etc. because we don't have their measurements and by including a lagged dependent variable because it contains the effects of these variables. In column 1, S\&P market share rise by 0.0048 in 1-year time as the 
percentage of IG ratings given by $1 \%$ and this value is not statistically significant because it is not different from zero. Also, market share shows a decrease by 0.02083 after one year due to $1 \%$ of IG ratings assigned by Moody's. However, the market share of S\&P shows an escalation by $1.13300 \%$ and $0.26170 \%$ in one year later due to increase in market share of Moody's \& Fitch by $1 \%$ individually. The value of R-squared highlights that the $35.39 \%$ variations represents by all the one lagged variable. In column 2 , market share of Moody's shows a huge increase by $7.425 \%$ in one year later due to increase in $1 \%$ of IG ratings assigned by Moody's. This value is statistically significant at 5\% level means different from zero. Also, the Moody's market share also indicates the growth of 2.840 in one year later due increase in market share of Fitch by $1 \%$. This value is statistically significant at $10 \%$ because different from zero. In column 3, Fitch market share growth by 0.01426 in one year later due to $1 \%$ increase of IG ratings and this value is statistically significant at $5 \%$ level. The Fitch market share dropped down by 5.457 due to $1 \%$ fall in market share of Moody's. The value of R-squared shows that $59.960 \%$ variation explained by other independent variables.

Table 2. OLS Estimates based on percentage of IG Assigned with 1 Year Lagged

\begin{tabular}{|c|c|c|c|c|c|}
\hline & \multicolumn{5}{|c|}{ OLS Estimates } \\
\hline & $\begin{array}{c}\text { Dependent variable: } \\
\text { SP ms }\end{array}$ & & $\begin{array}{c}\text { Dependent variable: } \\
\text { Moodys ms }\end{array}$ & & $\begin{array}{c}\text { Dependent variable: } \\
\text { Fitch ms }\end{array}$ \\
\hline \multirow[t]{2}{*}{ const } & 0.26920 & const & $-2.538^{*}$ & const & 0.16760 \\
\hline & -1.51300 & & -1.16900 & & -0.34410 \\
\hline \multirow[t]{2}{*}{ Moodys ms 1} & 1.13300 & Fitch ms 1 & $2.840^{*}$ & SP IG 1 & $-0.04789 *$ \\
\hline & -3.71500 & & -1.18300 & & -0.02215 \\
\hline \multirow[t]{2}{*}{ Fitch ms 1} & 0.26170 & SP IG 1 & $0.04300 * *$ & Moodys IG 1 & 0.09055 \\
\hline & -1.53100 & & -0.01699 & & -0.03895 \\
\hline \multirow[t]{2}{*}{ SP IG 1 } & 0.00488 & $\mathrm{SP}$ ms 1 & $-0.06972 *$ & Fitch IG 1 & $0.01426^{*}$ \\
\hline & -0.02198 & & -0.02988 & & -0.00869 \\
\hline \multirow[t]{2}{*}{ Moodys_IG_1 } & -0.02083 & Fitch_IG_1 & -0.00475 & SP_ms_1 & $3.101^{*}$ \\
\hline & -0.03866 & & -0.00667 & & -1.54200 \\
\hline \multirow[t]{2}{*}{ Fitch_IG_1 } & -0.00951 & Moodys IG 1 & $7.425 * *$ & Moodys ms 1 & $-5.457^{*}$ \\
\hline & -0.00863 & & -2.87100 & & -2.42100 \\
\hline $\mathrm{n}$ & 12 & $\mathrm{n}$ & 12 & $\mathrm{n}$ & 12 \\
\hline $\mathrm{R}^{2}$ & 0.35390 & $\mathrm{R}^{2}$ & 0.60140 & $\mathrm{R}^{2}$ & 0.59960 \\
\hline
\end{tabular}

Notes: * indicates significance at the 10 percent level; ** indicates significance at the 5 percent level.

Source: by author.

Table 3 demonstrates the outcomes of OLS appraisals of market share of CRA's as dependent variable against the percentage of IG assigned as independent variable. While market share regress against the percentage IG grades given with 2 years lag. The purpose of this lagged value is due to find more impacts of IG grade on market share because it is dependent on time and it also avoid the presence of autocorrelation in the model. Lagging the percentage of IG allows us to forecast their outcome in period ( $\mathrm{t}$ ) established on the data of period $(\mathrm{t}-2)$. In column 1 , the $\mathrm{S} \& \mathrm{P}$, market share shows an increase of by $0.00080 \%$ in 2 -year time due $1 \%$ assigning of IG given by S\&P. whereas, market share falls by $0.2525 \%$ in 2 years' time due to $1 \%$ market share of Moody's 2 years later means that the market shares are dependent on \% of IG ratings. Also, the R-squared shows that $37.55 \%$ variations in market share of S\&P clarify by the variables shown. In column 2, the market share of Moody's shows a rise of $0.00787 \%$ in 2 years late due to $1 \%$ increase in percentage of IG ratings given by Moody's. The Moody's market share shows a fall of $0.0054 \%$ and $0.0029 \%$ in 2-year time due $1 \%$ increase in IG ratings assigned by Fitch and S\&P. Moreover, the R-squared indicates the $58.310 \%$ variations in Moody's market share by independent variable in 2 years' time. In column 3, Fitch market share highlights an increase of $0.01865 \%$ after 2 year due to $1 \%$ increase in IG ratings assigned by Fitch and this is showing a decline of due to \% IG of assigned by other two CRA's. While, the Fitch market share shows and increase of $0.06967 \%$ and $0.2114 \%$ with 2 year lagged due to increase of $1 \%$ in market of S\&P and Moody's. However, the R-squared is the highest among other two agencies shows that the $66.77 \%$ variation explains by the independent variables shown.

Table 3. OLS Estimates based on percentage of IG Assigned with 2 Year Lagged

\begin{tabular}{|c|c|c|c|c|c|}
\hline & \multicolumn{4}{|c|}{ OLS Estimates } & \multirow[b]{2}{*}{$\begin{array}{l}\text { Dependent variable: } \\
\text { Fitch ms }\end{array}$} \\
\hline & $\begin{array}{c}\text { Dependent variable: } \\
\text { SP_ms }\end{array}$ & & $\begin{array}{l}\text { Dependent variable: } \\
\text { Moodys_ms }\end{array}$ & & \\
\hline const & 0.48550 & const & 0.51130 & const & 0.04164 \\
\hline & -0.37190 & & -0.37830 & & -0.40430 \\
\hline Moodys ms 1 & -0.25250 & SP ms 1 & -0.10810 & $\mathrm{SP} \mathrm{ms} 1$ & 0.06967 \\
\hline & -0.54230 & & -0.43610 & & -0.41080 \\
\hline
\end{tabular}


Financial Markets, Institutions and Risks, Volume 4, Issue 1, 2020 ISSN (online) - 2521-1242 ISSN (print) - 2521-1250

Table 3 (cont.). OLS Estimates based on percentage of IG Assigned with 2 Year Lagged

\begin{tabular}{|c|c|c|c|c|c|}
\hline Fitch ms 1 & 0.26270 & Fitch $\mathrm{ms} 1$ & -0.30110 & Moodys ms 1 & 0.21410 \\
\hline & -0.44110 & & -0.32750 & & -0.37930 \\
\hline \multirow{2}{*}{ SP IG 2} & 0.00080 & SP IG 2 & -0.00298 & SP IG 2 & -0.00378 \\
\hline & -0.00468 & & -0.00376 & & -0.00436 \\
\hline \multirow[t]{2}{*}{ Moodys IG 2} & -0.00016 & Moodys IG 2 & 0.00787 & Moodys IG 2 & -0.00771 \\
\hline & -0.00941 & & -0.00757 & & -0.00876 \\
\hline \multirow[t]{2}{*}{ Fitch IG 2} & -0.01322 & Fitch IG 2 & -0.00543 & Fitch IG 2 & 0.01865 \\
\hline & -0.01049 & & -0.00844 & & -0.00977 \\
\hline $\mathrm{n}$ & 11 & $\mathrm{n}$ & 11 & $\mathrm{n}$ & 11 \\
\hline $\mathrm{R}^{2}$ & 0.37550 & $\mathrm{R}^{2}$ & 0.58310 & $\mathrm{R}^{2}$ & 0.66770 \\
\hline
\end{tabular}

Notes: * indicates significance at the 10 percent level; ** indicates significance at the 5 percent level.

Source: by author.

Table 4 displays the OLS estimates market share of each CRA as dependent variable against number of IG ratings assigned by them and each grade of credit ratings regress against market share of CRA's. This is because better understanding of impacts on market share on the basis of number ratings assigned by CRA's. The AAA ratings coefficient estimated in column 2 shows that when the increase in Moody's market share by $0.1890 \%$ on average rise in number of AAA ratings by 1 unit for given set of banks which is statistically significant at $10 \%$. The coefficient of AA+ ratings calculates in column $1 \& 2$ that when the market share of Fitch \& Moody's increases by 0.0527 and 0.1323 on average rise in number of AA+ ratings by 1 unit respectively. Meanwhile, there is no effect on market share of S\&P showing a nil value because they are assigning this type of ratings for a chosen set of banks. However, if we see further in table, the situation is totally different because the coefficient of AA- ratings guesses in table that when market share of Fitch, Moody's and S\&P increases by $0.0547,0.0132$ and 0.0253 on average increase in number of AA- ratings by 1 unit correspondingly. So, market share is increasing for all CRA's with respect to number AA- ratings assign for set of banks and Fitch market share is increasing more as compare to Moody's and S\&P.

The coefficient of AA ratings approximates that the increase in Fitch \& Moody's market share by 0.049, 0.080 $\%$ on average rise in number AA ratings by 1 unit for each. Here, market share of Moody's is increasing more by generously giving number of ratings for set of banks but Fitch market share is increasing by assigning less AA ratings, this may be due to other type of ratings may be given instead for that. The coefficient of A+ ratings evaluates that rise in Fitch and S\&P market share by $0.0299,0.01849 \%$ on average an increase in number of A+ ratings by 1 unit respectively. So, here market share of S\&P is increasing more among the other two ratings agencies and Moody's in this case assigning negligible number of ratings which does not affect its market share enough. The A ratings coefficient determines that growth in Fitch, moody and S\&P market share by $0.0444,0.05,0.02 \%$ on average increase in number of ratings assigned by 1 unit respectively. Moody's market share is increasing more than other two agencies due to assigning high number of A ratings to set of banks. Also, the coefficient of A- ratings determines that decrease (increase) in Fitch, Moody's and S\&P market share by $0.1200(0.01,0.0298) \%$ on average increase in number of ratings assigned by 1 unit correspondingly. In this case, S\&P market share is more than the other two rating agencies because it assigns more number of A- ratings so it is leading in this grid as compare its competitors. The coefficient of BBB+ ratings estimates that drop down (increase) in market share of Fitch, Moody's and S\&P market share by $0.1152(0.06,0.170) \%$ on average increase in number of IG ratings assigned by 1 unit. Moreover, Moody's market share is greater than other two because it assigns more generously than other agencies. Whereas, S\&P market share also increases but they issued very less number of ratings. The BBB ratings coefficient determines that increase in market share of Moody's by $0.0345 \%$ due to rise in number of ratings assigned by. The market share of Moody's is greater than other two ratings agencies and S\&P issue a less number of ratings that's why its market share increase less than this. In last coefficient BBB-ratings only Moody's issued less significant number of ratings and other two do not issue significant ratings, so they are ignored. R-squared value indicates that the data is fitted with regression. In this model, the value of R-squared for Fitch is $74 \%$ but for Moody's \& S\&P got value of $98 \%$ each. So, this indicates that the models explain the variability of the response data around its mean because their value is very close to $100 \%$. This shows that all models fit the chosen data set and the respective percentages explain the variation explains by the independent variables in the models. 
Table 2. OLS Estimates based on Individual Grades Assigned by CRA's

\begin{tabular}{|c|c|c|c|}
\hline \multicolumn{4}{|c|}{ OLS Estimates } \\
\hline & $\begin{array}{c}\text { Dependent variable: } \\
\text { Fitch_ms }\end{array}$ & $\begin{array}{c}\text { Dependent variable: } \\
\text { Moody_ms }\end{array}$ & $\begin{array}{c}\text { Dependent variable: } \\
\text { SP_ms }\end{array}$ \\
\hline AAA & - & $0.189088^{*}$ & - \\
\hline $\mathrm{AA}+$ & $0.0527090 *$ & -0.132341 & - \\
\hline AA- & 0.0547 & $0.0132 *$ & 0.025300 \\
\hline $\mathrm{AA}$ & 0.0498336 & 0.0800 & - \\
\hline $\mathrm{A}+$ & $0.0299625 * *$ & 0 & 0.018490 \\
\hline $\mathrm{A}$ & 0.0444626 & 0.0500 & 0.013449 \\
\hline A- & -0.120005 & $0.01 * *$ & $0.02987 * *$ \\
\hline $\mathrm{BBB}+$ & -0.115262 & 0.0600 & 0.170000 \\
\hline $\mathrm{BBB}$ & - & 0.0345773 & - \\
\hline BBB- & - & 0 & - \\
\hline $\mathrm{R}^{2}$ & 0.7400 & 0.9800 & 0.9800 \\
\hline
\end{tabular}

Notes: * indicates significance at the 10 percent level; ** indicates significance at the 5 percent level. Source: by author.

\subsubsection{Fitch}

The figure 14 represents actual and predicted market share of Fitch based on the number of ratings assigned. Based on number of ratings assigned, actual market share of Fitch is increasing for the period. Whereas, the predicted market share is showing a decreasing trend, this is due to increase in restrictions after the financial crisis, so they are less generous in assigning the higher ratings to banks.

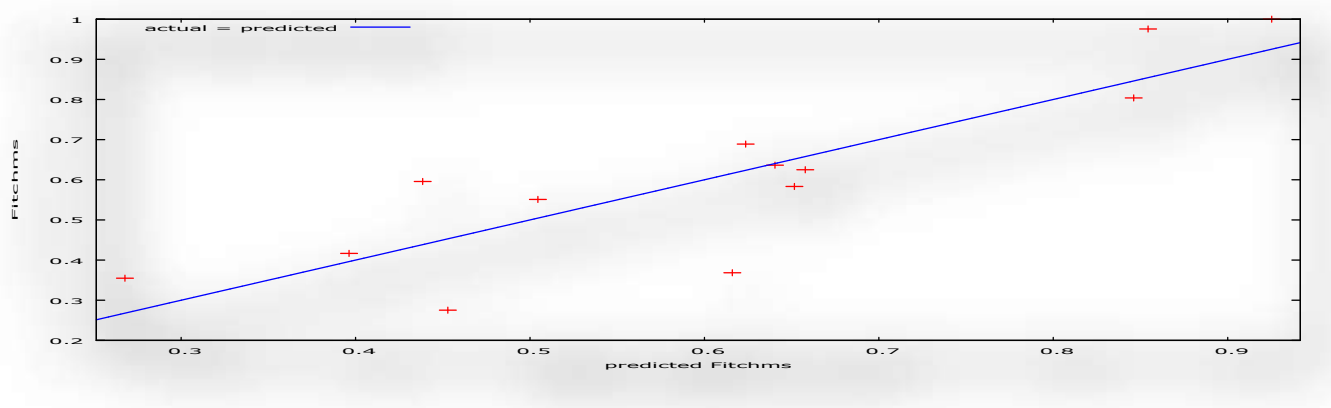

Source: by author.

Figure 14. Fitch Predicted Market Share

\subsubsection{Moody's}

The figure 15 shows that Moody's actual market share is greater than the predicted market share. As the trend line shows that Moody's market share is dependent on number of ratings assigned for period of (2006-2018). Predicted market share is drop down due adjustment in ratings criteria.

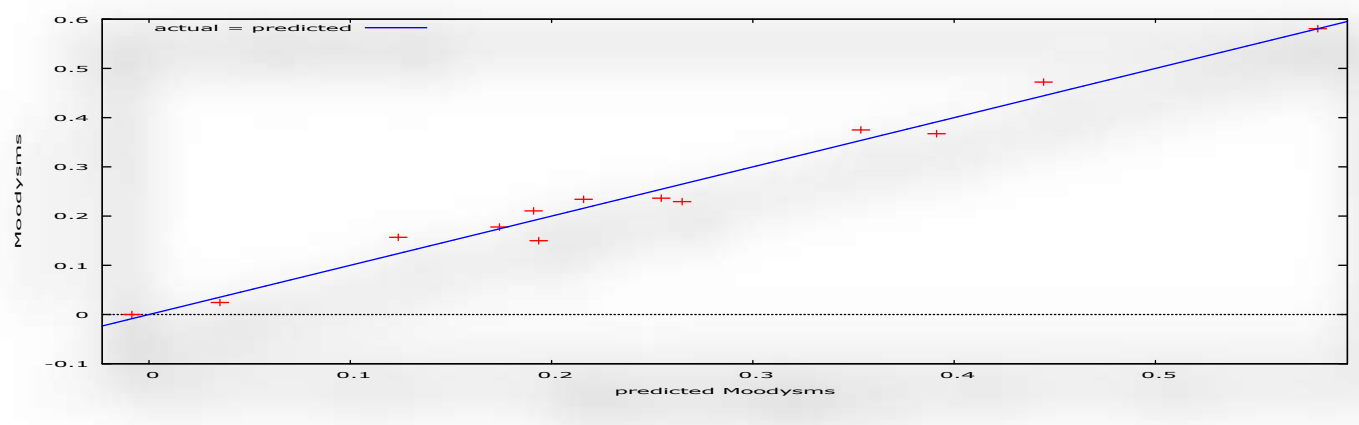

Figure 15. Moody's Predicted Market Share

Source: by author. 


\subsubsection{S\&P}

The figure 16 represents that $\mathrm{S} \& \mathrm{P}$ actual market share is less than estimated market share based on investigation period. This is due to a less number of ratings assigned by S\&P and in future market share of Fitch is increasing trend because as the trend line increase S\&P assign more ratings for this set of banks.

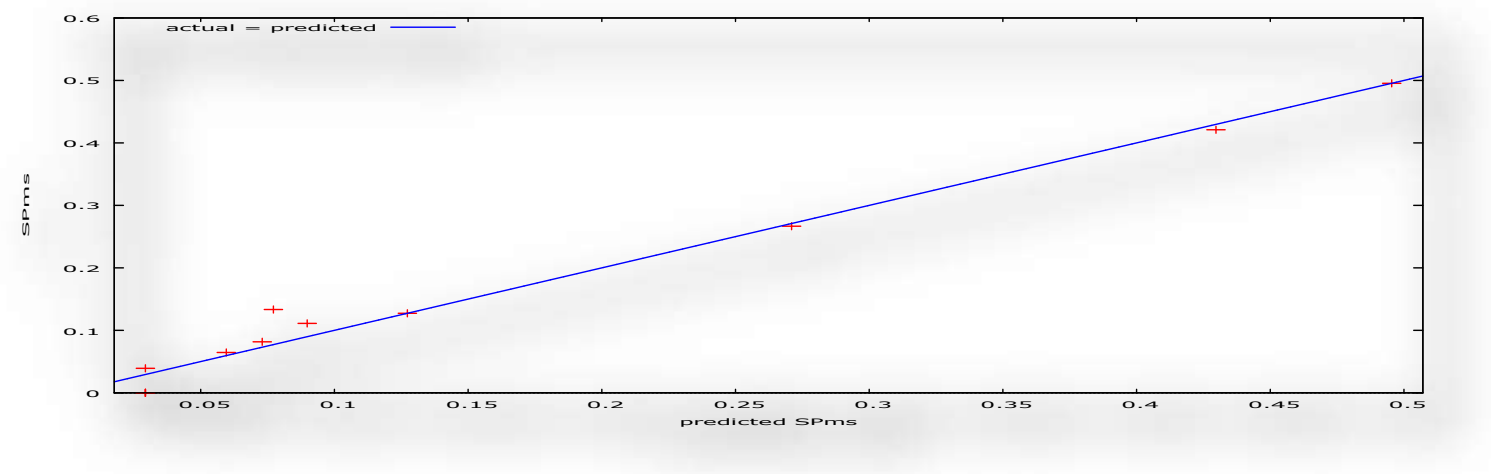

Figure 16. S\&P Predicted Market Share

Source: by author.

\subsection{Discussion}

This part evaluates the results and collected data in the light of literature review (chapter 2). The results will be investigated with the purpose of finding the relation between the percentage of investment grades and CRA's market share. Furthermore, we will assess the influences of financial crisis on agencies market share by viewing their modelling and ratings standard. Also, we will debate the alteration made by CRA's in their ratings standards and their impacts on market share. Finally, at the completion of this section all the key research questions will be responded with discussing the reliability and soundness of this research. Credit evaluations is a procedure by which trustworthiness of an organization can be evaluated which established on issuer's worth of assets, obligations and its entire corporate performance. If the CRA's manipulate these scores just for the sake of enhancing their market share by assigning higher ratings. Hence, we performed a series of tests which mainly focus on assessing the relationship between CRA's and their market share. First, we tested the percentage of IG assigned by CRA's against their market share. The results from table 1 displays that the $\%$ of IG ratings assigned by CRA's shows that the increase in market share due high percentage of ratings. Furthermore, there is a major positive correlation exits among CRA's market share against their \% of IG assigned which shows that higher percentage will leads to higher market share and vice versa. As figure 9 shows that in 2015, S\&P assigned higher percentage ratings in that year which shows a massive increase in its market share in figure 10 as compare Fitch and Moody's. Also, high percentage of IG ratings pushes the CRA's towards high rivalry which might lead them to compromise their ratings standards for the sake of increasing their market share and this shows a strong relation among rivalry vs high ratings quality consistent with theories where rivalry cause high quality of ratings. As, we see that our findings are in line with Camanho et al. (2010) because they found that a reduction in inflated ratings due to rise in competition between CRA's and they have charged a high fee to become market leader but we found direct relation between percentage of IG ratings and market share of CRA's.

The predicted constants could be undependable in table 1 because no controls are involved. So that in table 2 $\& 3$, we resolve this dispute by presenting a lag of year 1 and year 2 respectively which evaluate the effects of higher ratings on market share because it's impacts appear in later years in later years which decrease the value of R-squared. The results are very much confirming our hypothesis because it is very clear that for every increase in investment grades, the market share shows a high trend for CRA's. Likewise, Milbourn and Becker (2011) also found the similar result for Fitch market share shows an increase with the rise in level of ratings assigned but they didn't talk about investment grade ratings we focus on both quality and quantity for top banks in the world because their ratings decision influence worldwide investors. For testing the relationship high quality ratings and market share, in table 3 the results show that individual ratings against market share. The results show that the high quality of ratings cause an increase their market share of that year. Meanwhile, the high-quality ratings increase the environment of competition between CRA's which act as a positive sign for the market share. In regression analysis the market share of Fitch shows a positive correlation with respect 
to different grades (AA+ to A) of ratings with higher values especially for $\mathrm{AA}+$ with $0.0527 \%$. Likewise, from figure 8 indicates that Fitch assigns high quality ratings from $\mathrm{AA}+$ to $\mathrm{A}$ which reflected high bars (green) as compare to others because IG ratings are common under competition which shows the importance of firm to CRA's with respect to its market share and more probability of charging the lower ratings in case of switching their services. These results are in line with the Faltin-Traeger et al. (2009) examine the CRA's market share with relation to firms on the basis of favorable ratings assignment in early years. In deduction, we can argue that the regression analysis and figures confirm that the high \% of IG given by CRA's cause an increase in their market share. Hence, market share of CRA's are directly proportion to the percentage of IG assigned by them.

Due to emergence of financial crisis and Dodd-Frank Wall Street and Consumer protection Act (2010) leads the CRA's to adjust their Rating standards and maintain a healthy ethical business atmosphere for the best interest of investors. If we realize the growth rate of CRA's based on number ratings in figure $12 \& 13$ illustrates that there not any massive growth due to these events because mostly show a negative growth rate and they remain more protective for their reputation. In accordance to the Salvador et al. (2014) analyses the effects of financial crisis on Spanish banking system by using probit model and found that average banks rating fall by $13 \%$. In our sample, the number of ratings in crisis period are very less which are in line with these results because figure 9 indicates that there is a drop-in credit rating and also the figure 7 shows that Fitch assign a greater number of ratings than its competitors. However, there are other key factors in which CRA's differ such as size, number of clients and size of clients need to be considered. According to figure 8 the number of investment grade ratings assigned by Fitch more than other two ratings agencies which indicated that Fitch lead their competitors in our sample. But According to Reuter News Big three almost hold 95\% of the market share in witch Moody's and S\&P own major of the part. There are also country specific factors influence the credit ratings e.g. political, economic etc. According to BBC News, UK has lost its top AAA ratings from S\&P due to Brexit vote by saying "the referendum results could lead to a deterioration of UK's economic performance, including its large financial services sector". Hence, these factors may restrict the CRA's in assigning number of ratings for different sector which operate in that country and in this they might neglect more generously giving more percentage of investment grades ratings.

\subsection{Chapter's Conclusion}

In conclusion, it can be stated that CRA's market share is dependent on number and quality of ratings assigned because more they allocate high quality ratings more, they capture the market share in sector. Also, CRA's market share depends on the size of agency, number of clients and the embedded inherent risk in their business. Due to effects of financial crisis, the evaluation of new regulations and hardening of ratings criteria's and there is a significant fall in the number of ratings which cause a significant reduction in market share of CRA. There is general factor such as economic, political and loan etc. conditions also effect the credit ratings. Also, the interest rates and purchasing power of each country effects the credit ratings factors because these are vital parts in finding a country's specific economic condition. Moreover, size of banks also matters like JP Morgan have key products, customers and investors which spread around the world as compare to Yorkshire building society. So, CRA's did concern about their ratings standards for each bank because their ratings allocation has impacts on stakeholders around the globe.

\section{Conclusions}

Credit ratings plays a significant role in financial system and improving their performances through decreasing information asymmetric between stakeholders. In this research, we examine the impacts on market share of CRA's due high percentage of investment grade assigned through general analysis and econometric analysis and the results from both analyses are inline by proving the impact of each other. By using a sample of banks credit ratings from UK and USA from 2006-2018, we found clear evidence that high percentage of investment grades ratings have a direct relation with CRA's market share. But market share might be impacted because issuers may pay high fee according to their ratings preferences which might influence ratings quality. At the same time, CRA's must look about their reputational consequences because these may affect their decisionmaking process due to emergence of financial Tsunami \& Dodd-Frank Act leads them to harden their ratings standards and protect customers which results in fall in number of ratings from CRA's.

Also, we found that the quality and quantity of ratings assigned by CRA's have a favorable increase in their market share in that year. For better analysis of CRA's market share we used lagged the variables because its impact found in the later years. So, we detected that due to high percentage of investment grade ratings having 
positive impacts on market share of CRA's in later years and illustrate a positive correlation among each other. The competition between CRA's might affect this market share because as the competition increase, they might ignore their criteria's to retain their customers base by assigning high quality ratings. This might lead them to conflict of interest because as already Moody's senior president claims that the analysts are harassed for giving high ratings to client. For regulators and legislators, it is value for considering that growing rivalry in industry may ignore the reputational damage for the sake of increasing the market share. Moreover, there are some country specific factors like economic and political situation which could affect their market share of CRA's because they must downgrade or upgrade according to their specific conditions. Also, the CRA's are differ in size and number of clients because these factors are directly related to market share as from reports "Big Three" holds $95 \%$ of market share in world so they really concern about their position in the industry. But the size of client also matters because the more clients is large more its gain high quality ratings from CRA's which mean that a large number of stakeholder's relay on that ratings.

Finally, by viewing the results from testing and different factors, it can be deduced that the market share of CRA's driven by high percentage of Investment grades given. The CRA's are more generous in assigning more quality ratings just for sake of increasing their market share.

\subsection{Research Limitations}

This study was limited by certain number of aspects such as the availability of data is limited because of providing only access to Fitch-Connect instead of Bank Scope which leads to neglect certain factors such accounting, economic etc. Moreover, there is a literature gap regarding this research topic as most of studies didn't talk about generosity of CRA's in assigning high quality and quantity ratings versus their market share because they only talk about competition, reputational effects, conflict of interest and fee effects with respect to their market share. Similarly, the results show very minor figures in OLS estimates due to small sample size of banks because only 21 banks ratings are accounted for this research. Likewise, there might be a problem regarding comparison of different banks as in the sample we incorporated the top banks of UK and USA that might be differ in size and nature of business \& operations that might affect the ratings assignment. So, this factor might lead to inadequate comparison because political and economic factors are different for each set of banks and this might restrict the CRA's regarding assigning quality ratings that could impact their market share.

\subsection{Further Research}

The further research can be carried out by using research outcomes of this study. As we didn't incorporate the country specific factors for each firm such as political and economic situational variables in the model testing so we can include that to improve better exploration. We can also incorporate accounting factors such as profitability, leverage, and return on asset, total assets and revenues of each firm with comparison to their market share for better judgement of outcomes. Additionally, there are firm specific factors such as size of firm and nature of clients for each CRA because they differ in these capacities, these factors can be accounted for enhanced analysis of market share with respect to high percentage of IG given. In addition to that we can increase the sample size upon different continents by making a comparative study such as Europe, Asia etc. regardless country specific banks. For CRA's we can introduce the dummies of reputational, competition and conflict of interest on credit ratings with respect to market share so that a more comprehensive effects of IG can be found out. Lastly, we can also add variables regarding finding out the effect of financial crisis by calculation of asset situation for each bank and its impact on market share of CRA's.

\section{References}

1. Allen, D. E., Powell, R., and Singh, A. (2013). A Dynamic Credit Ratings Model', Edith Cowan University Publications 373. Available at: http://www.mssanz.org.au/modsim2013/F5/allen.pdf

2. Bae, K., Kang, J., and Wang, J. (2015). Does Increased Competition Affect Credit Ratings? A Reexamination of the Effect of Fitch's Market Share on Credit Ratings in the Corporate Bond Market'. Journal of Financial and Quantitative Analysis 50 (5), 1011-1035. https://doi.org/10.1017/ S0022109015000472

3. Balland, P., Déprés, C., Billard, R., and Tabourot, L. (eds.) (2011). AIP Conference Proceedings. 'Physically Based Kinematic Hardening Modelling of Single Crystal': 1353, 1, 91-96. https://doi.org/ 10.1063/1.3589497

4. Bank of England (2011). Whither the credit ratings industry?' Financial Stability Paper, 9. 
Financial Markets, Institutions and Risks, Volume 4, Issue 1, 2020 ISSN (online) - 2521-1242 ISSN (print) - 2521-1250

5. $\quad$ BBC NEWS (2016) Ratings Agencies Downgrade UK Credit Rating after Brexit Vote. Available at: https://www.bbc.co.uk/news/business-36644934

6. Becker, B. and Milbourn, T. (2011). How did Increased Competition Affect Credit Ratings? Journal of Financial Economics 101 (3), 493-514. https://doi.org/10.1016/j.jfineco.2011.03.012

7. Bheemanaguda, R. and Madegowda, K. (2010). Performance appraisal for Indian Credit Ratings Agencies. 8. Bolton, P., Freixas, X., and Shapiro, J. (2012). The Credit Ratings Game. The Journal of Finance 67(1), 85-111, https://doi.org/10.1111/j.1540-6261.2011.01708.x

9. Bryman, A. and Bell, E. (2015) Business Research Methods [online]: Oxford University Press, USA

10. Camanho, N., Deb, P., and Liu, Z. (2010). Credit Rating and Competition' Lse Financial Markets Group, Discussion paper series, 653

11. Cantor, R. and Packer, F. (1995). The Credit Rating Industry. The Journal of Fixed Income, 5(3), 10-34. Available at: https://pdfs.semanticscholar.org/13ca/4a9d128a5b2e18f8404aef0e77af2957070f.pdf

12. Caporale, G. M., Matousek, R., and Stewart, C. (2011). EU Banks Rating Assignments: Is there Heterogeneity between New and Old Member Countries?' Review of International Economics 19(1), 189-206. https://doi.org/10.1111/j.1467-9396.2010.00940.x

13. Cohen, A. and Manuszak, M. D. (2013). Ratings Competition in the CMBS Market, Journal of Money, Credit and Banking 45 (s1), 93-119. https://doi.org/10.1111/jmcb.12040

14. Dimitrov, V., Palia, D. and Tang, L. (2015). Impact of the Dodd-Frank act on credit ratings, Journal of Financial Economics, 115(3), 505-520. https://doi.org/10.1016/j.jfineco.2014.10.012

15. DeYoung, R. and Torna, G. (2013) 'Non-traditional Banking Activities and Bank Failures during the Financial Crisis', Journal of Financial Intermediation 22 (3), 397-421. https://doi.org/10.1016/ j.jfi.2013.01.001

16. Easterby-Smith, M., Thorpe, R., and Jackson, P. R. (2012). Management Research [online]: Sage

17. Faltin-Traeger, O., Johnson, K. W., and Mayer, C. (2010). Issuer Credit Quality and the Price of Asset Backed Securities'. American Economic Review 100 (2), 501-505. DOI: 10.1257/aer.100.2.501

18. Farhi, E., Lerner, J., and Tirole, J. (2013) 'Fear of Rejection? Tiered Certification and Transparency'. The Rand Journal of Economics 44 (4), 610-631. https://doi.org/10.1111/1756-2171.12033

19. Fimalac. (2016). Annual Report. Available at: http://www.fimalac.com/items/files/ f5ecf37beb048fc 109c9b 760808cb432 FIMALAC--Rapport-annuel--exercice-2016-english-version.pdf.

20. Financial Crisis Inquiry Commission, United States of America, The Financial Crisis Inquiry Report (2011). Available at: $\mathrm{http}: / /$ fcic.law.stanford.edu/

21. Foley, S. (2013). Rating agencies: Outlook unchanged. Financial Times. [Online] Available at: https://www.ft.com/content/38d48444-5e3d-11e2-a771-00144feab49a\#axzz2QnNFC81Y

22. Global Fitch Rtings (2018). Bank Rating Criteria, Master Criteria. Bank Rating Criteria. [online] Fitch Ratings. Available at: https://www.fitchratings.com/site/re/10034713

23. Graham, J. R. and Harvey, C. R. (2001). The Theory and Practice of Corporate Finance: Evidence from the Field'. Journal of Financial Economics 60 (2-3), 187-243. https://doi.org/10.1016/S0304-405X(01)00044-7

24. Griffin, J. M. and Tang, D. Y. (2012). Did Subjectivity Play a Role in CDO Credit Ratings?'. The Journal of Finance 67 (4), 1293-1328. https://doi.org/10.1111/j.1540-6261.2012.01748.x

25. Hill, C. A. (2004). Regulating the Rating Agencies'. Wash.ULQ 82, 43. Available at: https://openscholarship.wustl.edu/law lawreview/vol82/iss1/2/

26. Hirth, S., 2014. Credit rating dynamics and competition. Journal of Banking \& Finance, 49, 100-112. https://doi.org/10.1016/j.jbankfin.2014.08.011

27. ICAP GROUP S.A. (2013) Credit Ratings Assignment Methodology [online] Credit Risk Services. Greece: ICAP GROUP S.A. Available at: https://www.icap.gr/Images/ICAP\%20Group\% 20\%20Credit\%20Ratings\% 20 Assignment\%20Methodology.pdf $>$

28. IMF (International Monetary Fund) (2010). The uses and abuses of sovereign credit ratings. Global financial stability report", October 2010

29. Jiang, J. X., Stanford, M. H., and Xie, Y. (2012) 'Does it Matter Who Pays for Bond Ratings? Historical Evidence'. Journal of Financial Economics 105 (3), 607-621. https://doi.org/10.1016/ j.jfineco.2012.04.001

30. Judge, G. G., Hill, R. C., Griffiths, W., Lutkepohl, H., and Lee, T. C. (1982) 'Introduction to the Theory and Practice of Econometrics.' https://www.academia.edu/11975688/The Theory and Practice of Econometrics 31. Karminsky, A. M. and Khromova, E. (2016) 'Extended Modeling of Banks' Credit Ratings'. Procedia Computer Science 91, 201-210

32. Kartasheva, A. and Yilmaz, B. (2013). Precision of Ratings' [ebook] Bank for International Settlements, University of Pennsylvania. Available at: https://pdfs.semanticscholar.org/ 1025/26b63e2fbfbe50e0de696 82a88dd0058c459.pdf. 
Financial Markets, Institutions and Risks, Volume 4, Issue 1, 2020

ISSN (online) - 2521-1242 ISSN (print) - 2521-1250

33. Katz, L. (2008). Ratings Agencies and Their Methodology." in Ratings Agencies and Their Methodology [online] held 2008 at Washington D.C. World Bank/IMF. Available at: https://siteresources.worldbank.org/FINANCIALSECTOR/Resources/GRatingAgencies\&TheirMethodologiesLauraFeinlandKatz.pdf>

34. Katz, J.G., Munoz, E.S. and Stephanou, C. (2009). Credit rating agencies: No easy regulatory solutions. The World Bank Group, Financial and Private Sector Development Vice Presidency, Crisis Response Policy Brief, 8.

35. Kristina, B. (2013). Credit Rating Agencies (Cras). The EU Regulatory Framework Assessment, Bachelor of Business Administration Helsinki, Metropolia University of Applied Sciences.

36. Kudva, R. (2010). A Business Model for Rating Agencies: Learning from the CRISIL Experience [online] CRISIL, A Standard \& Poor's Company. Available from http://siteresources.worldbank.org/ FINANCIALSECTOR/Resources/Session5 RoopaKudva presentation.pdf $>$.

37. Lucchetti, A. (2008). Big Credit-Rating Firms Agree To Reforms. The Wall Street Journal [online] Available at: https:/www.wsj.com/articles/SB121268203224348921>

38. Mixon Jr, J. (2009). GRETL: An Econometrics Package for Teaching and Research, Managerial Finance $36(1), 71-81$

39. Moody's Investor Services. (2020). Rating symbols and Definitions for January 2020. Available at: https://www.moodys.com/sites/products/AboutMoodysRatingsAttachments/MoodysRatingSymbolsandDefinitio ns.pdf

40. Moody's Investor Services, (2016) Moody's Corporation Annual Report on Form 10-K for the year ended December 31, 2016. Available at: http://d18rn0p25nwr6d.cloudfront.net/CIK-0001059556/795d327d-c6b9-48dd8437-d82865accb86.pdf.

41. Moody's Investors Service ("MIS'). (2018). Procedures and Methodologies Used to Determine Credit Ratings. [online] Moody's Investors Service. Available at: https://www.moodys.com/sites/products/ ProductAttachments/Exhibit2.pdf.

42. Moody's Investors Service, Global Research Centre (2006). Moody's Credit Rating Prediction Model. Report Number: 100722. [online] Moody's Investors Service. Available at: https://www.moodys.com/sites/ products/DefaultResearch/2006200000425644.pdf

43. Morgan, D. P. (2002) 'Rating Banks: Risk and Uncertainty in an Opaque Industry'. American Economic Review 92 (4), pp.874-888. DOI: 10.1257/00028280260344506

44. Muñoz, C. S., Monsálvez, J. M. P., and de Guevara Radoselovics, Juan Fernández (2012). Impact of the Subprime Crisis on Bank Ratings: The Effect of the Hardening of Rating Policies and Worsening of Solvency'. Documentos De Trabajo (Fundación BBVA) (12), 3-42. Available at: http://www.grupobbva.com/ TLFU/dat/DT 12 2012 web.pdf

45. Neate, R. (2011) "Ratings Agencies Suffer 'Conflict Of Interest', Says Former Moody's Boss". THE GUARDIAN [online] Available at: https://www.theguardian.com/business/2011/aug/22/ratings-agencies-conflictof-interest>

46. ̈̈ğüt, H., Doğanay, M. M., Ceylan, N. B., and Aktaş, R. (2012) 'Prediction of Bank Financial Strength Ratings: The Case of Turkey'. Economic Modelling 29 (3), 632-640. https://doi.org/10.1016/ j.econmod.2012.01.010

47. Owlett, R. H. and Yu, F. (2016) 'A Re-Examination of Rating Shopping and Catering using Post-Crisis Data on CDOs'. Economics Letters 147, 164-167. https://doi.org/10.1016/j.econlet.2016.08.031

48. Packer, F. and Tarashev, N. A. (2011) 'Rating Methodologies for Banks', BIS Quarterly Review, June

49. Pastor, J. M., Salvador, C., and de Guevara, J. F. (2014). Impact of the Subprime Crisis on Bank Ratings: The Effect of the Hardening of Rating Policies and Worsening of Solvency, Journal of Financial Stability 11, 1331. https://doi.org/10.1016/j.jfs.2013.10.005

50. Peresetsky, A. A., Karminsky, A. A., and Golovan, S. V. (2011) 'Probability of Default Models of Russian Banks, Economic Change and Restructuring 44 (4), 297-334

51. Ramakrishnan, S. and Scipio, P. (2016). Big three in credit ratings still dominate business. Reuters. [Online] Available at: https://uk.reuters.com/article/uscorpbonds-ratings-idUKL2N17U1L4 [Accessed Aug. 2018].

52. Rating Agencies and the Use of Credit Ratings Under the Federal Securities Laws, Securities Act Release Nos. 8236, 47972, 68 Fed. Reg. 35258 (June 12, 2003). Available at: http://www.sec.gov/rules/ 
Financial Markets, Institutions and Risks, Volume 4, Issue 1, 2020 ISSN (online) - 2521-1242 ISSN (print) - 2521-1250

53. Rutledge, A. (2016). How the Credit Rating Agency Game Is Changing. Forbes. [online] Available at: https://www.forbes.com/sites/annrutledge/2016/04/04/how-the-credit-rating-agency-game-ischanging/\#37ce2aa64e78

54. S\&P Global Inc. Annual Report on Form 10-K for the year ended December 31, 2016, available at:http://investor.spglobal.com/Cache/38247824.PDF?O=PDF\&T=\&Y=\&D=\&FID=38247824\&iid=4023623

55. Salvador, C., de Guevara Radoselovics, Juan Fernández, and Monsálvez, J. M. P. (2014) 'The Adjustment of Bank Ratings in the Financial Crisis: International Evidence'. Documentos De Trabajo FUNCAS (750), 1. https://doi.org/10.1016/j.najef.2018.01.001

56. Saunders, M., Lewis, P., and Thornhill, A. (2009). Research Methods for Business Students [online] : Pearson education.

57. Saunders, M., Lewis, P., and Thornhill, A. (2009). Research Onion'. Research Methods for Business Students, 136-162

58. SEC (Securities and Exchange Commission) (2008). Summary report of issues identified in the Commission Staff's Examinations of Select Credit Rating Agencies. July 2008

59. Seetharaman, A., Kumar Sahu, V., Saravanan, A. S., Rudolph Raj, J., and Niranjan, I. (2017). The Impact of Risk Management in Credit Rating Agencies'. Risks, 5 (4), 52. https://doi.org/10.3390/risks5040052

60. Shen, C., Huang, Y., and Hasan, I. (2012). Asymmetric Benchmarking in Bank Credit Rating'. Journal of International Financial Markets, Institutions and Money 22 (1), 171-193. https://doi.org/10.1016/j.intfin.2011.08.004

61. Skreta, V. and Veldkamp, L. (2009) 'Ratings Shopping and Asset Complexity: A Theory of Ratings Inflation'. Journal of Monetary Economics 56 (5), 678-695

62. Standard \& Poor's Ratings Services (2014). What are credit ratings and how do they work? [Online] Guide to credit rating essentials. Standard \& Poor's Ratings Services Magraw Hill Financials. Available from https://www.spratings.com/documents/20184/760102/SPRS_UnderstandingRatings_GRE.pdf/298e606f-ce5b4ece-9076-66810cd9b6aa

63. Stanton, R. and Wallace, N. (2011) 'the Bear's Lair: Index Credit Default Swaps and the Subprime Mortgage Crisis'. The Review of Financial Studies 24 (10), 3250-3280. https://doi.org/10.1093/rfs/hhr073

64. Strier, F. (2008). Rating the Raters: Conflicts of Interest in the Credit Rating Firms'. Business and Society Review 113 (4), 533-553. https://doi.org/10.1111/j.1467-8594.2008.00331.x

65. Sundmacher, M. and Ellis, C. (2011). Bank 'ratings Arbitrage': Is LGD a Blind Spot in Economic Capital Calculations?' International Review of Financial Analysis 20 (1), 6-11. https://doi.org/ 10.1016/ j.irfa.2010.11.001

66. The Guardian (2012). How credit rating agencies rule the world. Available at https://www.theguardian.com/business/2012/feb/15/credit-ratings-agencies-moodys

67. The New York Times (2009). Moody's Official Concedes Failures in Some Ratings. Available at: https://www.nytimes.com/2008/01/26/business/26moodys.html

68. The Use of Credit Ratings by Financial Intermediaries Article 5(A) Of the CRA Regulation (2014) European Securities and Markets Authority

69. U.S. Securities and Exchange Commission, MCMXXXIV (2017) Annual Report On Nationally Recognized Statistical Rating Organizations [online] Section 6 of the Credit Rating Agency Reform Act of 2006. Available from $<$ https://www.sec.gov/ocr/reportspubs/annual-reports/2017-annual-report-on-nrsros.pdf $>$

70. UK Government Actuary's Department (2018). Investment News. Insurance and Investment Team. [online] UK: Institute and Faculty of Acturies, UK. Available at: https://assets. publishing.service. gov.uk/government/uploads/system/uploads/attachment_data/file/718731/May_2018_update.pdf

71. US Exchange commission (2016) (2010). Competition And Credit Rating Agencies. OCED Hearings. [Online] Directorate for Financial and Enterprise Affairs Competition Committee. Available at: Https://Www.Oecd.Org/Competition/sectors/46825342.pdf [Accessed Aug. 2018].

72. White L.J. (2002). The Credit Rating Industry: An Industrial Organization Analysis. In: Levich R.M., Majnoni G., Reinhart C.M. (eds) Ratings, Rating Agencies and the Global Financial System. The New York University Salomon Center Series on Financial Markets and Institutions, 9. Springer, Boston, MA

73. White, L. J. (2010). Markets: The Credit Rating Agencies, Journal of Economic Perspectives 24 (2), 211 226, DOI: $10.1257 /$ jep.24.2.211

74. Wilson, J. (2014). Essentials of Business Research: A Guide to Doing Your Research Project [online]: Sage. Available at: https://journals.sagepub.com/doi/abs/10.1177/097215091101200211

75. Xia, H. (2014). Can Investor-Paid Credit Rating Agencies Improve the Information Quality of Issuer-Paid Rating Agencies?' Journal of Financial Economics 111 (2), 450-468. https://doi.org/10.1016/ j.jfineco.2013.10.015 


\title{
Appendix
}

\section{Ethics Approval Certificate}

\section{Coventry \\ University}

\author{
Certificate of Ethical Approval \\ Applicant: \\ Muhammad Aslam \\ Project Title: \\ is credit rating agency market share driven by the ratings given? \\ This is to certify that the above named applicant has completed the Coventry \\ University Ethical Approval process and their project has been confirmed and \\ approved as Low Risk
}

Date of approvat:

12 June 2018

Project Reference Number:

P72089

Table 1. Ratings Assigned

\begin{tabular}{|c|c|c|c|c|c|c|}
\hline \multirow{2}{*}{ Banks } & \multicolumn{3}{|c|}{ Number of Ratings } & \multicolumn{3}{|c|}{ weight in Sample } \\
\hline & Fitch & Moody's & S\&P & Fitch & Moody's & $\mathrm{S} \& \mathrm{P}$ \\
\hline JP Morgan Chase \& Co & 20 & 9 & 6 & $5 \%$ & $5 \%$ & $5 \%$ \\
\hline Goldman Sachs Bank & 14 & 6 & 8 & $4 \%$ & $3 \%$ & $6 \%$ \\
\hline CITI Group & 26 & 5 & 4 & $7 \%$ & $3 \%$ & $3 \%$ \\
\hline Bank of America Corporation & 31 & 13 & 6 & $8 \%$ & $7 \%$ & $5 \%$ \\
\hline Morgan Stanley \& Co & 23 & 8 & 4 & $6 \%$ & $4 \%$ & $3 \%$ \\
\hline Well Fargo \& Co & 17 & 15 & 8 & $4 \%$ & $8 \%$ & $6 \%$ \\
\hline The Bank of New York Mellon Corporation & 17 & 9 & 4 & $4 \%$ & $5 \%$ & $3 \%$ \\
\hline U.S Bancorp & 14 & 6 & 2 & $4 \%$ & $3 \%$ & $2 \%$ \\
\hline PNC Financial Services Group & 18 & 5 & 2 & $5 \%$ & $3 \%$ & $2 \%$ \\
\hline TD Bank US Holding Company & 15 & 6 & 4 & $4 \%$ & $3 \%$ & $3 \%$ \\
\hline Barclays plc & 21 & 10 & 10 & $5 \%$ & $5 \%$ & $8 \%$ \\
\hline Lloyds Banking Group plc & 19 & 7 & 8 & $5 \%$ & $4 \%$ & $6 \%$ \\
\hline HSBC Holdings plc & 18 & 4 & 6 & $5 \%$ & $2 \%$ & $5 \%$ \\
\hline Santander UK Group Holdings plc & 5 & 6 & 2 & $1 \%$ & $3 \%$ & $2 \%$ \\
\hline The Royal Bank of Scotland Group plc & 22 & 3 & 10 & $6 \%$ & $2 \%$ & $8 \%$ \\
\hline Nationwide Building Society & 22 & 23 & 12 & $6 \%$ & $13 \%$ & $9 \%$ \\
\hline Standard Chartered PLC & 14 & 2 & 10 & $4 \%$ & $1 \%$ & $8 \%$ \\
\hline Close Brothers Group PLC & 9 & 6 & 7 & $2 \%$ & $3 \%$ & $5 \%$ \\
\hline Coventry Building Society & 18 & 17 & 3 & $5 \%$ & $9 \%$ & $2 \%$ \\
\hline National Westminster Bank Plc & 28 & 20 & 13 & $7 \%$ & $11 \%$ & $10 \%$ \\
\hline Yorkshire Building Society & 19 & 2 & 0 & $5 \%$ & $1 \%$ & $0 \%$ \\
\hline Total & 390 & 182 & 129 & $100 \%$ & $100 \%$ & $100 \%$ \\
\hline
\end{tabular}

Source: by author. 
Table 2. Grades of Ratings

\begin{tabular}{|c|c|c|c|c|c|c|c|c|}
\hline \multicolumn{2}{|c|}{ Ratings } & Scale 10 & \multicolumn{2}{|c|}{ Fitch } & \multicolumn{2}{|c|}{ Moody's } & \multicolumn{2}{|c|}{ Standard \& Poor's } \\
\hline \multirow{4}{*}{$\underset{\text { క }}{5}$} & AAA & 10 & 0 & $0 \%$ & 1 & $1 \%$ & 0 & $0 \%$ \\
\hline & $\mathrm{AA}+$ & 9 & 35 & $9 \%$ & 18 & $10 \%$ & 5 & $4 \%$ \\
\hline & AA- & 8 & 98 & $25 \%$ & 21 & $12 \%$ & 4 & $3 \%$ \\
\hline & AA & 7 & 34 & $9 \%$ & 13 & $7 \%$ & 7 & $5 \%$ \\
\hline \multirow{6}{*}{ 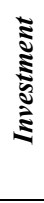 } & $\mathrm{A}+$ & 6 & 77 & $20 \%$ & 30 & $16 \%$ & 8 & $6 \%$ \\
\hline & $\mathrm{A}$ & 5 & 89 & $23 \%$ & 33 & $18 \%$ & 36 & $28 \%$ \\
\hline & A- & 4 & 15 & $4 \%$ & 40 & $22 \%$ & 28 & $22 \%$ \\
\hline & $\mathrm{BBB}+$ & 3 & 10 & $3 \%$ & 13 & $7 \%$ & 23 & $18 \%$ \\
\hline & $\mathrm{BBB}$ & 2 & 13 & $3 \%$ & 5 & $3 \%$ & 8 & $6 \%$ \\
\hline & BBB- & 1 & 19 & $5 \%$ & 8 & $4 \%$ & 10 & $8 \%$ \\
\hline \multicolumn{3}{|c|}{ Total Ratings } & 390 & $100 \%$ & 182 & $100 \%$ & 129 & $100 \%$ \\
\hline
\end{tabular}

Source: by author.

Table 3. Market Share Analysis

\begin{tabular}{|c|c|c|c|c|c|c|c|}
\hline \multirow{2}{*}{$\begin{array}{ll}\text { Year of } \\
\text { Ratings }\end{array}$} & \multicolumn{4}{|c|}{ Number of Observation } & \multicolumn{3}{|c|}{ Market share } \\
\hline & Fitch & Moody's & $S \& P$ & Total & Fitch & Moody's & $S \& P$ \\
\hline 2006 & 40 & 1 & 0 & 41 & $98 \%$ & $2 \%$ & $0 \%$ \\
\hline 2007 & 35 & 13 & 7 & 55 & $64 \%$ & $24 \%$ & $13 \%$ \\
\hline 2008 & 41 & 8 & 2 & 51 & $80 \%$ & $16 \%$ & $4 \%$ \\
\hline 2009 & 40 & 24 & 0 & 64 & $63 \%$ & $38 \%$ & $0 \%$ \\
\hline 2010 & 24 & 0 & 0 & 24 & $100 \%$ & $0 \%$ & $0 \%$ \\
\hline 2011 & 35 & 9 & 16 & 60 & $58 \%$ & $15 \%$ & $27 \%$ \\
\hline 2012 & 28 & 11 & 8 & 47 & $60 \%$ & $23 \%$ & $17 \%$ \\
\hline 2013 & 21 & 12 & 24 & 57 & $37 \%$ & $21 \%$ & $42 \%$ \\
\hline 2014 & 31 & 8 & 6 & 45 & $69 \%$ & $18 \%$ & $13 \%$ \\
\hline 2015 & 30 & 25 & 54 & 109 & $28 \%$ & $23 \%$ & $50 \%$ \\
\hline 2016 & 27 & 18 & 4 & 49 & $55 \%$ & $37 \%$ & $8 \%$ \\
\hline 2017 & 22 & 36 & 4 & 62 & $35 \%$ & $58 \%$ & $6 \%$ \\
\hline 2018 & 16 & 17 & 4 & 37 & $43 \%$ & $46 \%$ & $11 \%$ \\
\hline Total & 390 & 182 & 129 & 701 & $56 \%$ & $26 \%$ & $18 \%$ \\
\hline
\end{tabular}

Source: by author.

Table 4. Growth Rate Analysis

\begin{tabular}{|c|c|c|c|}
\hline \multirow{2}{*}{ Year of Ratings } & \multicolumn{3}{|c|}{ Growth Rate } \\
\hline & Fitch & Moody's & $S \& P$ \\
\hline 2006 & $0 \%$ & $0 \%$ & $0 \%$ \\
\hline 2007 & $-35 \%$ & $869 \%$ & $13 \%$ \\
\hline 2008 & $26 \%$ & $-34 \%$ & $-69 \%$ \\
\hline 2009 & $-22 \%$ & $139 \%$ & $-100 \%$ \\
\hline 2010 & $60 \%$ & $-100 \%$ & $0 \%$ \\
\hline 2011 & $-42 \%$ & $15 \%$ & $27 \%$ \\
\hline 2012 & $2 \%$ & $56 \%$ & $-36 \%$ \\
\hline 2013 & $-38 \%$ & $-10 \%$ & $147 \%$ \\
\hline 2014 & $87 \%$ & $-16 \%$ & $-68 \%$ \\
\hline 2015 & $-60 \%$ & $29 \%$ & $272 \%$ \\
\hline 2016 & $100 \%$ & $60 \%$ & $-84 \%$ \\
\hline 2017 & $-36 \%$ & $58 \%$ & $-21 \%$ \\
\hline 2018 & $22 \%$ & $-21 \%$ & $68 \%$ \\
\hline Total & $29 \%$ & $-43 \%$ & $70 \%$ \\
\hline
\end{tabular}

Source: by author. 